\title{
OTIMIZAÇÃO DA CRIAÇÃO DE Ageniaspis citricola Logvinovskaya, 1983 (Hymenoptera: Encyrtidae) EM LABORATÓRIO E SUA ADAPTAÇÃO NO ESTADO DE SÃO PAULO
}

\author{
PATRÍCIA MILANO \\ Bióloga
}

Orientador: Prof. Dr. JOSÉ ROBERTO POSTALI PARRA

Dissertação apresentada à Escola Superior de Agricultura "Luiz de Queiroz", Universidade de São Paulo, para obtenção do título de Mestre em Ciências, Área de Concentração: Entomologia.

P I R A C I C A B A

Estado de São Paulo - Brasil

Janeiro -2002 


\section{Dados Internacionais de catalogação nà Publicação (CIP) DIVISĀO DE BIBLIOTECA E DOCUMENTAÇĀO - ESALQ/USP}

\section{Milano, Patrícia}

Otimização da criação de Ageniaspis citricola, Logvinoskaya, 1983 (Hymenoptera : Encyrtidae) em laboratório e sua adaptação no Estado de São Paulo / Patrícia Milano. - - Piracicaba, 2002.

68 p. : il.

Dissertação (mestrado) - - Escola Superior de Agricultura Luiz de Queiroz, 2002. Bibliografia.

1. Controle biológico (Fitossanidade) 2. Criação massal 3. Frutas cítricas 4. Insetos parasitas 5. Lagarta-minadora I. Título

CDD 632.781

\section{Termitida a copia total ou parcial deste documento, desde que citada a fonte -0 autor:}




\section{Agradeço a Deus}

pelas oportunidades concedidas

Ao meu amado namorado Marcelo pelo carinho e apoio.

Ofereço

Aos meus amados pais Edson e Meire, pelo amor, incentivo e confiança que sempre dedicaram, fornecendo-me força para atingir meus objetivos e a me tornar quem sou. Aos meus queridos e estimados avós Rosa, Ulysses (in memorian) e Aída pelo enorme carinho e apoio que sempre me dedicaram.

Dedico 


\section{AGRADECIMENTOS}

- Ao Dr. José Roberto Postali Parra, Professor do Departamento de Entomologia, Fitopatologia e Zoologia Agrícola, da ESALQ/USP, pela oportunidade, amizade, orientação, confiança, apoio e compreensão;

- Ao Pesquisador Pedro Takao Yamamoto pelo apoio na realização dos trabalhos e ao Fundo Paulista de Defesa da Citricultura (FUNDECITRUS), pelo suporte financeiro;

- A Helton C. Leão pelo apoio e a Celso Nogueira, Eng. ${ }^{\text {ss }}$ Agrônomos da Fischer S/AAgropecuária, pelo grande apoio na realização dos trabalhos de campo bem como a Gaspar e todos os técnicos e "pragueiras" das fazendas do estado de São Paulo pertencentes ao citado grupo.

- Aos professores do Departamento de Entomologia, Fitopatologia e Zoologia Agrícola, da ESALQ/USP, pelos ensinamentos transmitidos;

- Ao Dr. Evôneo Berti Filho, Professor Associado da ESALQ/USP, pela amizade, compreensão e pelas oportunidades concedidas;

- Ao Dr. Marcone C. M. das Chagas da EMBRAPA, EMPARN, Natal, RN, pelos ensinamentos transmitidos. 
- Á minha amiga Neide G. Zério, técnica do Laboratório de Biologia de Insetos do Departamento de Entomologia, Fitopatologia e Zoologia Agrícola da ESALQ/USP, pela amizade, carinho, apoio, companheirismo e confiança que sempre dedicou;

- Aos meus amigos Renata e Fernando Cônsoli, Lusinério Prezoti e Elizabeth B. Bernardi pelo apoio, carinho, companheirismo e confiança que sempre me dedicaram;

- À minha amiga Amanda Fialho, pela colaboração nos trabalhos e pela paciência, companheirismo e amizade dedicados;

- Aos amigos Rita C.R.G. Gervásio e a Ronaldo Reis pela inestimável ajuda na realização das análises estatísticas deste trabalho;

- Ao amigo Alexandre de Sene Pinto pelo companheirismo e pela valiosa ajuda na edição final deste trabalho;

- Ao Dr, Valmir A. Costa, do Instituto Biológico de Campinas, pela identificação das espécies de parasitóides citadas no trabalho e acima de tudo, pela valiosa amizade e companheirismo;

- A todos os amigos do Departamento, Peter, Rosa, Dori, Ana Lia, Ademir, Maurício, Adriana, Milena, Odinei, Eduardo, Silvia, Sandra, "Pacu", Solange, Aninha, Edilene, João Gorá, Moisés, "Seu Chico", João F., Paulo, Rosângela e Marcos "Paraíba";

- Aos funcionários de campo, Carlinhos, "Tutu" e "Dino" pelo coleguismo e préstimos oferecidos;

- As bibliotecárias Eliana Maria Garcia e Kátia Andrade pela revisão das referências bibliográficas e atenção dispensada. 


\section{SUMÁRIO}

Página

LISTA DE FIGURAS ............................................................................... viii

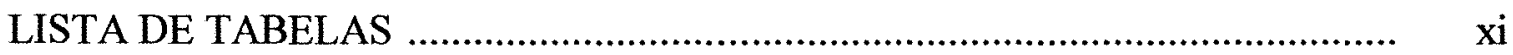

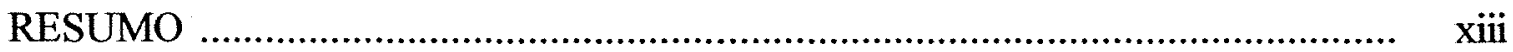

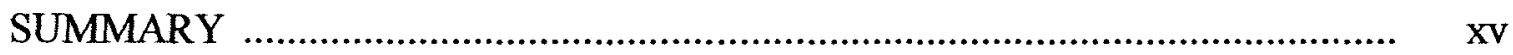

1 INTRODUÇÃO

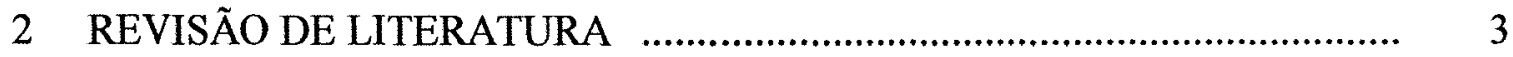

2.1 Características bioecológicas do minador-dos-citros, Phyllocnistis citrella Stainton, 1856 ................................................................................ 3

2.2 Distribuição geográfica ..................................................................... 5

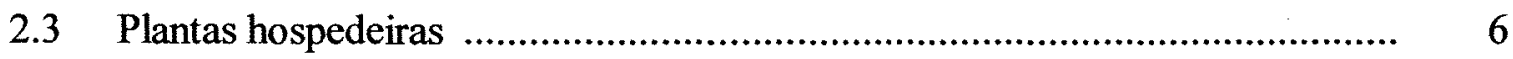

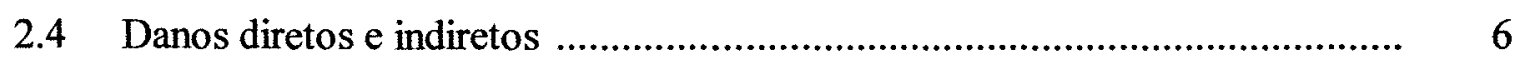

2.5 Controle biológico ................................................................................ 7

2.5.1 A ação dos parasitóides ......................................................................... 7

2.5.2. A ação dos predadores ......................................................................... 11

2.6 Ageniaspis citricola .............................................................................. 12

2.6.1. Distribuição geográfica ….................................................................... 12

2.6.2. Características bioecológicas ............................................................... 13

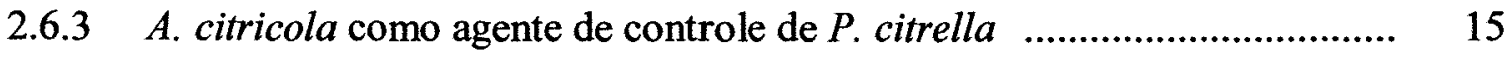

3 MATERIAL E MÉTODOS ….................................................................. 17

3.1 Criação de $P$. citrella $\quad$................................................................................. 17

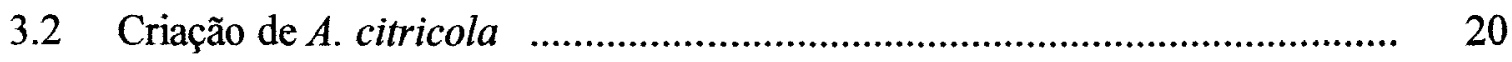


3.3 Otimização da criação de $A$. citricola $\quad$............................................................ 20

3.3.1 Número ideal de adultos de $P$. citrella por planta $\quad$.................................... 20

3.3.2 Efeito do tamanho de mudas de limão cravo e número de ovos de P.citrella por folha de citros, na obtenção de pupas do minador ................................ 22

3.3.3. Comportamento de oviposição de $P$. citrella em diferentes variedades de

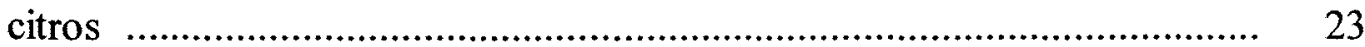

3.3.4 Parasitismo de $A$. citricola em ovos e/ou lagartas de $1^{\circ}$ ínstar de $P$. citrella 25

3.3.5 Influência de três temperaturas na biologia e capacidade de parasitismo de A. citricola

3.4. Comparação de técnicas de liberação de $A$. citricola em campo e da idade de pupas do parasitóide a serem colocadas nestes recipientes

3.5. Espécies de parasitóides nativos de $P$. citrella encontrados em pomares 1 ano após o início das liberações

3.6. Verificação da adaptação de $A$. citricola em pomares de laranja 3 anos após sua introdução no Brasil

4 RESULTADOS E DISCUSSÃO ….......................................................... 34

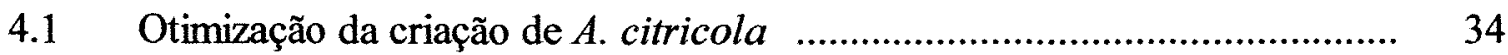

4.1.1 Número ideal de adultos de $P$. citrella por planta f.................................... 34

4.1.2 Efeito do tamanho de muda de limão cravo e número de ovos de $P$. citrella por folha de citros, na obtenção de pupas do minador ................................ 35

4.1.3. Comportamento de oviposição de $P$. citrella em diferentes variedades de citros

4.1.4 Parasitismo de $A$. citricola em ovos e/ou lagartas de $1^{\circ}$ ínstar de $P$. citrella

4.1.5 Influência de três temperaturas na biologia e capacidade de parasitismo de A. citricola

4.1.5.1 Capacidade de parasitismo e longevidade de fềmeas de A. citricola

4.1.5.2 Número de pupas de A. citricola por hospedeiro, viabilidade pupal e duração do período ovo-adulto do parasitóide em três temperaturas

4.2. Comparação de técnicas de liberação de $A$. citricola em campo e da idade de pupas do parasitóide a serem colocadas nestes recipientes 
4.3. Espécies de parasitóides nativos de P. citrella encontrados em pomares 1 ano após o início das liberações de $A$. citricola

4.4. Verificação da adaptação de $A$. citricola em pomares de laranja 3 anos após sua introdução no Brasil

5 CONCLUSÕES 


\section{LISTA DE FIGURAS}

Página

1 Etapas da criação de $P$. citrella: A. Mudas de limão em tubetes; B. Tubetes em bancadas em casa-de-vegetação; C. Plantas imersas em solução

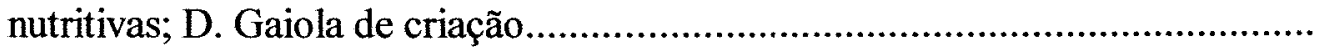

2 Gaiola de poliestireno utilizada no bioensaio para avaliação do número

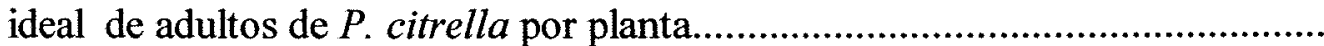

3 Etiquetas utilizadas para a marcação de folhas no teste de efeito do tamanho de mudas e números de ovos na obtenção de pupas de P.citrella........

4 Oviposição de $P$. citrella em diferentes variedades de citros. A. Gaiola utilizada no teste de livre escolha; B. Detalhe da base da gaiola para acomodação de tubetes; C. Gaiola utilizada no teste de confinamento.......

5 Capacidade de parasitismo de A. citricola em 3 temperaturas. A. Gaiola utilizada para avaliar a capacidade de parasitismo de $A$. citricola; $B$. Detalhe da tampa e base da gaiola; C. Tubos de emergência de $A$. citricola; D. Detalhe do tubo de emergência.

6 Comparação de técnicas de liberação de A. citricola em campo. A. Tubete utilizado para liberação com "voil” na extremidade; B. Copo plástico utilizado para liberação com "voil" na extremidade; C. Estrutura geral do copo com 
detalhes da manutenção da umidade; D. Distribuição dos tratamentos no pomar (Locais de instalação das diferentes idades de pupas de $A$ citricola em tubetes e copos...

7 Altitude dos Centros de serviços baseadas em cartas geográficas do IGC, IBGE e IGA das 16 fazendas pertencentes ao grupo FISCHER S/A Agropecuária onde foram realizadas as amostragens da porcentagem de parasitismo de A citricola

8 Correlação entre o número de ovos por folha colocados por P. citrella e porcentagem de pupas formadas. Temperatura $25 \pm 2{ }^{\circ} \mathrm{C}$, UR: $70 \pm 10 \%$ e fotofase 14h)

9 Média de ovos de $P$. citrella, em diferente variedades de citros, em teste de livre escolha e confinamento. Tratamentos; A: L. Volkameriano, B: C. carrisa, C: L. cravo, D: C. swingle, E: T. limonia. Temperatura $25 \pm 2^{\circ}$ C, UR: $70 \pm 10 \%$ e fotofase $14 \mathrm{~h}$

10 Porcentagem de parasitismo de ovos e lagartas de $1^{\circ}$ instar de $P$. citrella por A. citricola em teste de livre escolha e confinamento. Temperatura $25 \pm 2^{\circ} \mathrm{C}$, UR: $70 \pm 10 \%$ e fotofase $14 \mathrm{~h}$

11 Curvas de sobrevivência observada e esperada de 22 fêmeas de $A$. citricola nas temperaturas de 20,25 e $30^{\circ} \mathrm{C}$, UR: $70 \pm 10 \%$ e fotofase $14 \mathrm{~h}$, segundo o modelo de distribuição de Weibull.

12 Média de pupas e porcentagem de viabilidade pupal de A. citricola em três temperaturas, UR: $70 \pm 10 \%$ e fotofase $14 \mathrm{~h}$

13 Duração do período ovos - adulto de $A$. citricola a 20,25 e $30^{\circ}$ C, UR: $70 \pm 10 \%$ 


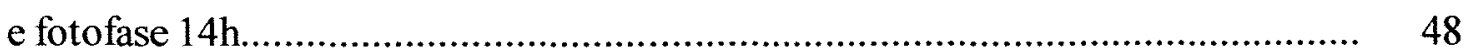

14 Macho de Ageniaspis citricola, com os dois primeiros antenômeros de

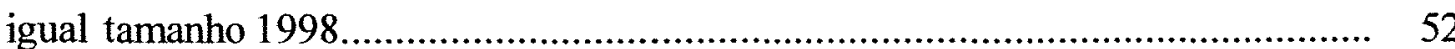

15 Adulto de Galeopsomyia fausta, parasitóide nativo mais abundante nas

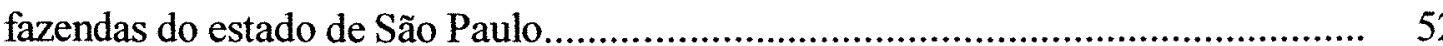

16 Porcentagem de parasitismo de $A$. citricola nas regiões norte, centro e sul do Estado de São Paulo 3 anos após a liberação do parasitóide em campo............... 55 


\section{LISTA DE TABELAS}

Página

1 Delineamento para avaliação de técinicas de liberação e observação da melhor idade de pupas de $A$. citricola no campo.

2 Número total de ovos de $P$. citrella/planta e número médio de ovos/folha, em limão cravo mantido em tubetes. Temperatura $25 \pm 2^{\circ} \mathrm{C}$, UR: $70 \pm 10 \%$ e fotofase $14 \mathrm{~h}$.

3 Porcentagem de pupas de $P$. citrella em diferentes tamanhos de mudas de limão cravo. Temperatura $25 \pm 2^{\circ} \mathrm{C}, \mathrm{UR}: 70+10 \%$ e fotofase $14 \mathrm{~h}$

4 Porcentagem de pupas de $P$. citrella a partir de diferentes números de ovos por folha de limão cravo em condição de laboratório em mudas de 10 meses e em tubetes. Temperatura $25 \pm 2^{\circ} \mathrm{C}, \mathrm{UR}: 70 \pm 10 \%$ e fotofase $14 \mathrm{~h}$.

5 Média de ovos de $P$. citrella, em diferentes variedades de citros, em teste de livre escolha e confinamento durante $48 \mathrm{~h}$. Temperatura $25 \pm 2^{\circ} \mathrm{C}$, UR: $70 \pm 10 \%$ e fotofase $14 \mathrm{~h}$

6 Parasitismo de $A$. citricola em ovos e/ou lagartas de $1^{\circ}$ instar de $P$. citrella medida pela formação de pupas (independente do número) em teste de livre escolha e confinamento durante $48 \mathrm{~h}$. Temperatura $25 \pm 2^{\circ} \mathrm{C}$, UR: $70 \pm 10 \% \mathrm{e}$ fotofase $14 \mathrm{~h}$ 
7 Porcentagem média de parasitismo de A. citricola e longevidade média das fêmeas em três temperaturas, UR: $70+10 \%$ e fotofase $14 \mathrm{~h}$.

8 Ocorrência (\%) de diferentes números de pupas de $A$. citricola hospedeiro a 20,

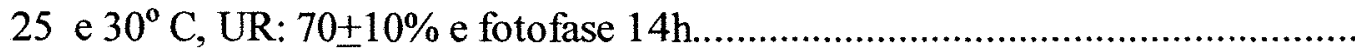

9 Freqüência média de pupas de $A$. citricola por hospedeiro, viabilidade pupal e duração do período ovo - adulto do parasitóide em três temperaturas,

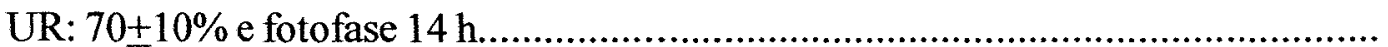

10 Comparação de técnicas de liberação de $A$. citricola em campo e da idade de pupas do parasitóide a serem colocadas nestes recipientes, em duas liberações realizadas em pomar de citros da ESALQ/USP.

11 Porcentagem de parasitismo na $1^{\mathrm{a}}$ e $2^{\mathrm{a}}$ amostragens de brotações de citros nas fazendas do estado de São Paulo pertencentes ao grupo FICHER

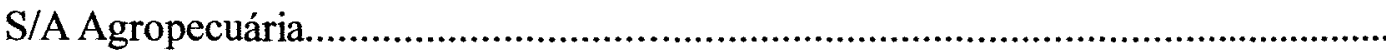




\title{
Otimização da criação de Ageniaspis citricola Logvinovskaya, 1983 (Hymenoptera: Encyrtidae) em laboratório e sua adaptação no estado de São Paulo
}

Autora: PATRÍCIA MILANO

Orientador: Prof. Dr. JOSÉ ROBERTO POSTALI PARRA

RESUMO

\begin{abstract}
A pesquisa teve como objetivo otimizar a criação em laboratório de Ageniaspis citricola Logvinovskaya, 1983, parasitóide específico de Phyllocnistis citrella Stainton, 1856, Lepidoptera - Gracillariidae, minador-dos-citros; bem como verificar a adaptação do parasitóide no Estado de São Paulo. Os bioensaios relacionados à otimização da criação de $A$. citricola foram desenvolvidos no laboratório de Biologia de Insetos do Departamento de Entomologia, Fitopatologia e Zoologia Agrícola da Escola Superior de Agricultura "Luiz de Queiroz" (ESALQ), campus de Piracicaba da Universidade de São Paulo (USP). A adaptação do parasitóide no Estado de São Paulo foi verificada através de levantamentos realizados no período de novembro de 2000 a fevereiro de 2001, em 16 pomares pertencentes ao grupo FISCHER S/A Agropecuária. Na otimização da criação de $A$. citricola, observou-se que a proporção de 2:1 (casais de $P$. citrella / planta) em tubetes foi a mais adequada para a obtenção de ovos para a criação do minador-dos-citros e do parasitóide. Em função dos resultados obtidos com mudas de citros de dois tamanhos, pode-se inferir que o sistema de produção de $P$.
\end{abstract}


citrella em tubetes é mais econômico, ocupando menos espaço do que o sistema em mudas de 10 meses facilitando experimentos em condições controladas. $\mathrm{O}$ comportamento do minador foi variável entre variedades de citros, em testes de confinamento e de livre escolha. Não existiu diferença de parasitismo por $A$. citricola entre ovos e lagartas de $1^{\circ}$ instar de $P$. citrella. Considerando-se a média de pupas por hospedeiro, viabilidade pupal e a duração do ciclo de $A$. citricola, deve ser recomendada a temperatura de $25^{\circ} \mathrm{C}$ para a criação do parasitóide em laboratório. Em liberações inoculativas, não houve diferenças na emergência de $A$. citricola em copos plásticos ou tubetes mantidos no campo e nem na idade das pupas a serem liberadas. $O$ parasitóide, três anos após sua introdução no Brasil, está completamente adaptado, especialmente nas regiões sul e centro do estado de São Paulo, predominando em relação à espécie mais abundante anteriormente à sua introdução, Galeopsomyia fausta LaSalle. 


\title{
Optimization of Ageniaspis citricola Logvinovskaya, 1983 (Hymenoptera: Encyrtidae) rearing and adaptation in the state of São Paulo
}

\author{
Author: PATRÍCIA MILANO \\ Adviser: Prof. Dr. JOSÉ ROBERTO POSTALI PARRA
}

SUMMARY

The goal of this research was to optimize the laboratory rearing of Ageniaspis citricola Logvinovskaya, 1983, a specific parasitoid of Phyllocnistis citrella Stainton, 1856 , Lepidoptera - Gracillariidae, the citrus leaf miner, as well as to verify the parasitoid adaptation in the state of São Paulo. The biological trials regarding the optimization of the rearing of A. citricola were developed at the Insect Biology laboratory of the Entomology, Plant Pathology and Agricultural Zoology of the Escola Superior de Agricultura "Luiz de Queiroz" (ESALQ), Piracicaba campus of the University of São Paulo (USP). The adaptation of the parasitoid in the state of São Paulo was verified through surveys performed from November 2000 through February 2001 in 16 groves belonging to FISCHER S.A. Agropecuária. At the A. citricola optimization one observed that the 2:1 proportion ( $P$. citrella couples / plant) in small tubes was the most adequate to achieve eggs to rear the citrus leaf miner and the parasitoid. According to the results obtained with two sizes of citrus seedlings one can infer that the producing system of $P$. citrella in small tubes is more economical, occupying less space than the 10 -month seedling system, thus making the experiments 
easier under controlled conditions. The behavior of the citrus leafminer varied among the citrus variety in confinement and free-choice tests. No difference of parasitism by $A$. citricola was observed in eggs and $1^{\text {st }}$ instar larvae of $P$. citrella. Considering the average number of pupae per host, the pupal viability and duration of the $A$. citricola cycle, the recommended temperature to rear the parasitoid in laboratory is $25^{\circ} \mathrm{C}$. In inoculative releases no differences regarding the emergence of $A$. citricola were observed in plastic cups or small tubes kept in the field nor on the age of the pupae to be released. Three years following the introduction of the parasitoid into Brazil, it is completely adapted, especially in the South and Central regions of São Paulo, and it prevails in relationship with the more abundant species prior to its introduction, the Galeopsomyia fausta LaSalle species. 


\section{INTRODUÇÃO}

O minador-dos-citros, Phyllocnistis citrella Stainton, 1856 (Lepidoptera: Gracillariidae), é uma mariposa de 4,0 $\mathrm{mm}$ de envergadura, que em sua fase larval, ataca as brotações cítricas, formando uma mina típica nas folhas, tornando-as retorcidas e de aspecto prateado (Heppner, 1993).

Os danos diretos causados por este inseto vão desde o comprometimento da fotossíntese até a queda prematura das folhas, culminando com o não desenvolvimento de brotações e queda do potencial produtivo dos pomares (Huang \& $\mathrm{Li}, 1989)$. Indiretamente, as minas provocadas pelas lagartas facilitam a entrada de microrganismos patogênicos (Sohi \& Sandhu, 1968; Cook, 1988), dentre os quais, a bactéria Xanthomonas axonopodis pv. citri, responsável pelo cancro cítrico, tem aumentado sensivelmente após a chegada do minador ao Brasil em 1996 (Massari citado por Chagas, 1999; Chagas et al., 2001).

Preocupados com o crescimento da infestação de $P$. citrella e o aumento do cancro cítrico observado desde a chegada desta praga, entidades públicas (ESALQ e EMBRAPA) e privadas (GRAVENA ManEcol Ltda e FUNDECITRUS) realizaram a importação e liberação de Ageniaspis citricola Logvinovskaya, 1983 (Hymenoptera: Encyrtidae) no estado de São Paulo a partir de outubro de 1998 (Parra, 2000; Parra et al., 2001) . A introdução deste parasitóide, ocorreu devido ao desconhecimento do potencial de controle dos inimigos naturais nativos face ao pouco tempo da presença da praga no país e aos grandes prejuízos por ela causados.

A escolha de $A$. citricola em relação a outros parasitóides testados em outros países, foi devido à constatação de seu sucesso na Austrália e EUA (Flórida) 
(Hoy e Nguyen, 1997) além de outros países como Peru (Sacarías \& Canales, 1999) e Israel (Argov \& Rössler, 1998).

O sucesso deste Encyrtidae introduzido em programas de controle clássico em vários países, deveu-se: a) à sua especificidade; b) alta taxa reprodutiva (poliembriônico); c) habilidade de localizar populações isoladas e pequenas do minadordos-citros, d) alta taxa de dispersão, o que lhe permite colonizar extensas áreas (Hoy e Nguyen, 1997; Hoy et al., 1997).

Assim, o objetivo da presente pesquisa foi a otimização da criação de $A$. citricola em laboratório visando à sua liberação em campo, bem como avaliar a sua adaptação no estado de São Paulo, três anos após sua introdução no Brasil. 


\section{REVISÃO DE LITERATURA}

\subsection{Características bioecológicas do minador-dos-citros, Phyllocnistis citrella Stainton, 1856}

O microlepidóptero $P$. citrella, conhecido por minador-dos-citros, pertence à família Gracillariidae e subfamília Phyllocnistinae (Cônsoli et al.,s.d.).

O minador-dos-citros é uma pequena mariposa, cujo adulto apresenta aproximadamente $4,0 \mathrm{~mm}$ de envergadura. As asas anteriores apresentam escamas de coloração branca a prata, brilhantes, plumosas, com pêlos escuros distribuindo-se longitudinalmente e transversalmente. $\mathrm{Na}$ região apical, as asas anteriores apresentam um ponto preto, característico da espécie (Heppner, 1993; Garijo \& Garcia, 1994; Smith \& Hoy, 1995; Alba,1996).

O dimorfismo sexual não é evidente entre os adultos (Alba, 1996; Jacas \& Garrido, 1996) embora, a parte terminal do abdome das fềmeas apresente duas pequenas faixas escuras de escamas que se estendem do sétimo ao nono segmento abdominal, podendo ser visualizadas lateralmente ao lóbulo do ovipositor, mediante observação em microscópio estereoscópico (Jacas \& Garrido, 1996). Graças a esta característica, a separação dos sexos, através de adultos, pode ser realizada facilmente em laboratório, evitando-se o manuseio das frágeis pupas do minador.

As posturas de $P$. citrella são realizadas em brotações novas, sendo os ovos colocados próximos à nervura principal das folhas, na maioria das vezes, na 
superficie abaxial das mesmas (Badawy, 1967; Sabine, 1971; Ba-Angood, 1977; Wilson, 1991; Chagas, 1999; Chagas \& Parra, 2000).

Os ovos de $P$. citrella são de difícil visualização a olho nu, sendo convexos, translúcidos e medindo $0,3 \times 0,2 \mathrm{~mm}$. Tornam-se mais visíveis próximos à eclosão, quando assumem coloração amarelo opaco (Batra et al., 1988; Garijo \& Garcia, 1994; Heppner, 1995; Alba, 1996).

Após a eclosão, as lagartas penetram nas folhas localizando-se no parênquima especializado e esponjoso levantando com seu corpo uma capa de epiderme, separando, portanto, a epiderme do parênquima (Sponagel \& Diaz, 1994). A subfamília Phyllocnistinae é caracterizada por seu modo hipermetamórfico e sua forma de alimentação nos estágios imaturos. Durante os primeiros ínstares, as lagartas, se nutrem da seiva de células cortadas e perfuradas pois têm aparato bucal especializado para uma forma de alimentação líquida; nos últimos ínstares, as lagartas se alimentam de tecido sólido devido à modificações no aparato bucal (Stehr, 1987).

Após a penetração no tecido foliar, as lagartas iniciam a construção de minas típicas em forma de serpentina e de coloração prateada, tornando as folhas retorcidas no final do ataque. Embora $P$. citrella tenha preferência por folhas novas, as lagartas podem se desenvolver no interior do pecíolo das brotações (Hutson \& Pinto, 1934; Sponagel \& Díaz, 1994) ou até mesmo em frutos (Sponagel \& Díaz, 1994; Heppner, 1995).

Normalmente, apenas uma lagarta se desenvolve por folha, podendo ocorrer de 2 a 3 lagartas/folha em altas infestações. Nestas condições, pode-se chegar ao extremo de se verificar o desenvolvimento de 9 a 20 minas/folha (Hutson \& Pinto, 1934; Pandey \& Pandey, 1964; Heppner, 1993). A pupação ocorre dentro da mina, em uma célula pupal característica, localizada na margem da folha, abaixo de uma porção enrolada da mesma (Heppner, 1993). 


\subsection{Distribuição geográfica}

A lagarta minadora-dos-citros, $P$. citrella foi descrita pela primeira vez por Stainton em 1856 a partir de espécimens coletados na Índia. Apesar de existirem relatos na literatura que indiquem a ocorrência desta praga no Irã e Iraque desde os anos $500 \mathrm{aC}$, o minador-dos-citros tem sua origem no sudeste asiático (Heppner, 1993).

O minador-dos-citros entrou na África e Austrália no início do século 20 (Heppner, 1993). Desde 1993 ele cruzou continentes, invadindo a Flórida (Heppner, 1993; Hoy \& Nguyen, 1994), o Caribe e a América Central.

Em 1994, P. citrella invadiu vários países do Mediterrâneo (Grécia, Itália, Marrocos, Espanha, Tunísia, Turquia etc) incluindo Israel dispersando-se posteriormente para vários estados americanos (Argov \& Rössler, 1998) e para países da América Central como México (Legaspi et al., 2001) e Cuba (Vazquez Moreno \& Perez Vicente, 1997).

Em 1995, o minador foi detectado na Colômbia (Garrido, 1995), Equador, Uruguai e Peru (Sacarías \& Canales, 1999).

Em 1996, observou-se a presença de P. citrella no Brasil (Prates et al., 1996), embora existisse preocupação com sua entrada no país desde 1994 (Lourenção et al., 1994, Gravena, 1994). O minador foi detectado primeiramente no estado de São Paulo sendo relatado posteriormente em vários estados brasileiros entre os quais, o Amazonas (Lopes et al., 1997), Roraima (Moreira et al. 1997), Rondônia (DAviles, 1997), Rio de Janeiro (Lima \& Aguiar, 1997), além dos estados do Tocantins, Piauí, Bahia, Mato Grosso do Sul, Goiás, Minas Gerais, Paraná (Lima e Aguiar, 1997; Nascimento \& Vidal, 1998; Didonet et al., 1998). Ao final de 1996, o minador também foi encontrado na Argentina onde dispersou-se rapidamente por todo o país (Sacarías \& Canales, 1999). 


\subsection{Plantas hospedeiras}

Heppner (1993) relatou a ocorrência de $P$. citrella principalmente em plantas da família Rutaceae, podendo também ser encontrada em representantes das famílias Oleaceae, Loranthaceae, Leguminosae e Lauraceae. Em alguns casos, apesar de ser evidenciada a presença de minas nestas quatro últimas famílias de plantas citadas, não ocorre o desenvolvimento completo do minador até o seu estágio adulto.

\subsection{Danos diretos e indiretos}

Os danos diretos causados pelo minador são, principalmente, redução na taxa de fotossíntese, queda de folhas, redução no crescimento e desenvolvimento de brotações e na produtividade, todos dependentes do nível de infestação da praga (Huang $\& \mathrm{Li}, 1989)$.

Os danos indiretos e mais preocupantes, devem-se ao fato de que as lesões podem servir de entrada para microorganismos, como a bactéria Xanthomonas axonopodis pv citri, responsável pelo cancro cítrico, além de fungos saprófitas como Alternaria spp. e Paecilomyces spp. os quais, normalmente não atacam folhas sadias (Sohi \& Sandhu, 1968; Cook, 1988).

As suspeitas de que o ataque do minador pudesse facilitar a disseminação da bactéria $X$. axonopodis pv citri, pôde ser constatada por alguns autores. Estudos de campo revelaram índices de infestação por esta bactéria de 11,1 a 27,3 e 58,6 a 75,0\%, respectivamente, na ausência e presença de danos de $P$. citrella (Sohi \& Sandhu, 1968).

Levantamentos realizados pelo FUNDECITRUS (Fundo Paulista de Defesa da Citricultura) demonstraram que o número de focos do cancro cítrico no Estado de São Paulo, após a chegada de $P$. citrella no Brasil em 1996, aumentou em, 
aproximadamente, 10 vezes ( de $45 \mathrm{em} 1996$ para $433 \mathrm{em} \mathrm{1998)} \mathrm{(Massari}{ }^{1}$ citado por Chagas, 1999; Chagas et al., 2001).

Chagas et al. (2001) puderam constatar que as fases imaturas do minadordos-citros foram responsáveis pelo aumento do cancro cítrico, pois em plantas inoculadas contendo lagartas de $2^{\circ}$ e $3^{\circ}$ ínstares ou pupas, ocorreram elevados percentuais de folhas infectadas pela bactéria, da ordem de $94,3,98,3$ e $100 \%$. Os autores constataram ainda que a taxa de infecção foliar pela bactéria, quando a folha foi lesionada, foi semelhante às taxas obtidas em folhas danificadas mecanicamente com posterior inoculação da bactéria. Os mesmos autores, evidenciaram que a bactéria penetra nas folhas pelos estômatos, porém, seu ataque é $50 \%$ menor quando comparado a folhas lesionadas por $P$. citrella.

Por outro lado, não foi possível constatar qualquer indício de aquisição do fitopatógeno pelo adulto do minador-dos-citros e , conseqüentemente, a transmissão da bactéria por esta fase do inseto (Chagas et al., 2001).

\subsection{Controle Biológico}

\subsubsection{A ação dos parasitóides}

Os dados obtidos na literatura, indicam que levantamentos sobre parasitóides e predadores, como possíveis agentes de controle de $P$. citrella, foram realizados em quase todos os países produtores de citros que tiveram seus pomares invadidos por esta praga. $\mathrm{O}$ controle promovido por parasitóides nativos dentro de cada país é muito variável no que se refere à espécie, porcentagem de controle e distribuição geográfica, bem como à adaptação e ação de parasitóides introduzidos.

Heppner (1993) relatou aproximadamente 30 espécies de parasitóides asiáticos de $P$. citrella envolvendo as famílias Encyrtidae, Pteromalidae, Eurytomidae,

${ }^{1}$ MASSARI, Informação pessoal transmitida a Chagas, 1999 
Elasmidae, Eupelmidae e Eulophidae, sendo a maioria deles pertencentes à família Eulophidae.

Schauff et al. (1998) apresentaram uma revisão, na qual foram descritos 41 gêneros de parasitóides, totalizando 80 espécies que, atacam o minador em várias regiões citrícolas de vários países.

$\mathrm{Na}$ Austrália, os parasitóides nativos Cirrospilus ingennus Gahan, Semielancher petiolatus Girault e Sympiensis sp., não tiveram efeito sobre o minador, tornando-se necessária a introdução de parasitóides exóticos dentre os quais, Ageniaspis citricola Logvinovskaya, 1983 e Cirrospilus quadristriatus Sulba Rao e Ramamani, que estabeleceram-se bem, conseguindo sobreviver no inverno. A. citricola, foi capaz de promover $90 \%$ de controle (Neale et al., 1995) além de dispersar-se por $300 \mathrm{~km}$ três anos após sua introdução (Hoy \& Nguyen, 1997).

Browning e Peña (1995) observaram que parasitóides nativos da Flórida, EUA, contribuíram para a manutenção de baixas populações de $P$. citrella, demonstrando que Pnigalio spp., Cirrospilus spp. e Horismenus spp. promoveram cerca de $50 \%$ de parasitismo em diferentes locais. Peña et al. (1996) observaram a flutuação da porcentagem de parasitismo de algumas espécies nativas. Dentre elas, Pnigalio minio Walker, apresentou baixas porcentagens de controle no inverno de 1994 (69 a 66\%), aumentando esta porcentagem na primavera de 1995 para 80\% de controle. Entretanto, o controle biológico exercido pelos parasitóides nativos foi inferior quando comparado àquele exercido por $A$. citricola, parasitóide exótico de origem asiática, importado da Austrália em 1994.

Smith \& Hoy (1995) desenvolveram a criação de dois parasitóides exóticos, A. citricola (Encyrtidae) e C. quadristriatus (Eulophidae) para liberação. Apesar da recuperação do eulofídeo, $A$. citricola foi mais eficiente promovendo $80 \%$ de controle e dispersando-se por 860.000 acres, sobrevivendo durante três invernos (Hoy \& Nguyen, 1997).

Em Israel, a ação dos parasitóides nativos não havia sido bem estudada, o que resultou na importação de espécies exóticas em 1994, tais como A. citricola, $C$. quadristriatus, Cirrospilus phyllocnistoides Narayanan, Quadrasticus sp (= Tetrastichus 
sp), S. petiolatus e Zaommomentedon brevipetiolatus Kamijo (Argov \& Rössler, 1996). Dentre estes parasitóides, destacaram-se $A$. citricola em 1995 , com $46 \%$ de controle e Quadrasticus sp (= Tetrastichus sp), que após um ano promoveu parasitismos variáveis de 37 a 84\% nas planícies costeiras de Israel e 13\% de parasitismo em área distante $2 \mathrm{~km}$ dos pontos de liberação (Argov e Rössler, 1998). Por outro lado, estes mesmos parasitóides que se destacaram em Israel, não promoveram grande controle do minadordos-citros quando introduzidos na Espanha, devido a fatores climáticos.

Quando P. citrella foi registrada em Málaga, Espanha (Garijo e Garcia, 1994), foram identificadas espécies de parasitóides nativos parasitando a espécie como: Pnigalio pectinicornis L., Cirrospilus sp. aff. a lyncus Walker, Cirrospilus pictus Nees, Cirrospilus vittatus Walker, Sympiensis sandanis Walker, Sympiensis gregori Boucek, Diglyphus isaea Walker e Chrysocharis pentheus Walker (Urbaneja, 1996). Dentre as espécies citadas, P. pectinicornis, Cirrospilus sp. aff. a lyncus e C. pictus foram as espécies mais abundantes no campo (Urbaneja et al., 1998) representando 57,1\%, 25,8\% e 11,2\%, do total de parasitóides encontrados. A. citricola e Quadrasticus sp., introduzidos em 1995 e 1996, respectivamente, representaram apenas 4,6 e 0,5\% do total de espécies observadas (Urbaneja et al., 2000). Nas Ilhas Canárias, A. citricola se constituiu em exceção, promovendo controle satisfatório.

Bautista et al. (1998) verificaram em Cuitlahuac, Veracruz, México, a presença de parasitóides nativos do minador. Galeopsomyia sp. e duas espécies de Cirrospilus , os quais promoveram 70\% de controle do minador-dos-citros entre 1995 1996.

Sacarías e Canales (1999) citaram o sucesso de A. citricola em 1994, que quando introduzido nas Ilhas Andros e Abaco, Bahamas, dispersando-se por 700 e 300 acres respectivamente, promoveram o controle total de $P$. citrella com níveis de parasitismo próximos a $100 \%$.

No Peru, $A$. citricola estabeleceu-se em $60 \%$ das áreas onde foi liberado, observando-se níveis de parasitismo de 30,1 a 100\% entre 1997 e 1998 (Sacarías e Canales, 1999). 
No Brasil, estudos preliminares realizados após a chegada do minador em 1996, apontaram Galeopsomyia sp. e Elasmus sp. como os parasitóides de P. citrella mais freqüentes (Sá \& Costa, 1997; Perioto, 1997); além destes, Penteado-Dias et al. (1997) encontraram representantes dos gêneros Cirrospilus, Pachyneuron (Pteromalidae) e Telenomus (Scelionidae). Em Jaguariúna, São Paulo, foram encontradas as seguintes espécies de parasitóides nativos: G. fausta, Cirrospilus sp. C, Elasmus sp. Eupelmus sp., Conura (Ceratosmicra) sp. e Chrysocharis sp. (Sá et al., 1999; Costa et al., 1999; Sá et al., 2000). Delas G. fausta foi o parasitóide mais abundante ocorrendo em 97,41\% das amostras (Sá et al. 1999) e 90\% (Costa et al. 1999).

Após sua introdução em Jaguariúna em 1998, A. citricola tornou-se predominante, representando $60,10 \%$ do total de parasitóides identificados, vindo a seguir, G. fausta com 38,30\% (Sá et al., 2000a). No entanto, esta porcentagem de parasitismo de A.citricola e G. fausta em Aguaí (SP), é diferente, embora as condições climáticas desta duas regiões sejam similares. Em Jaguariúna, o parasitismo de $A$. citricola foi de $20,0 \%$ e o de G. fausta de 5,6\% enquanto que em Aguaí, as porcentagens foram de 3,0\% e 22, 1\%, respectivamente (Sá et al., 2000b). Os autores atribuíram tais diferenças aos períodos de brotações variáveis nas 2 regiões.

A predominância de $A$. citricola sobre os parasitóides nativos, também foi descrita na Flórida, EUA por Pomerinke \& Stansly (1998), onde o parasitismo pelo encirtídeo passou de 2 para $86 \%$ no período de 18 meses, enquanto que o parasitismo pelos parasitóides nativos caiu de 30 para $2 \%$ no mesmo período. A literatura demonstra claramente a eficiência desta espécie, pois este parasitóide de ovos e lagartas de $1^{\circ}$ ínstar do minador, é capaz de dispersar-se rapidamente promovendo, na maioria das vezes, altas porcentagens de controle, motivo pelo qual ele tem sido utilizado em programas de controle do minador em vários países.

Dentre os parasitóides nativos, G. fausta é um eficiente agente controlador do minador juntamente com parasitóides do gênero Cirrospilus spp. em vários países. Os parasitóides do gênero Galeopsomyia estão distribuídos pela região Neotropical: incluindo México, Porto Rico, ocorrendo até a Argentina. São parasitóides associados a galhas, sendo $G$. fausta a única espécie generalista a atacar minadores 
(LaSalle \& Peña, 1997) e no caso de $P$. citrella, demonstra preferência pelo estágio pupal do minador (Costa et al., 1999).

Quanto ao gênero Cirrospilus, são várias as espécies descritas na Ásia, Oriente, Europa, nas Américas e Austrália (Schauff et al., 1998). Geralmente, atacam lagartas de $3^{\circ}$ ínstar do minador (Urbaneja et al., 2000). São ectoparasitóides solitários e/ou gregários facultativos ou não, de coleópteros, lepidópteros, dípteros e himenópteros podendo ser hiperparasitóides facultativos ou não (Sundby, citado por Urbaneja et al., 1998). A influência da temperatura no ciclo biológico de Cirrospilus sp. aff. próximo a lyncus, é descrita por Urbaneja et al. (2001), fornecendo dados importantes para a possível utilização desta espécie na região com clima mediterrânico.

\subsubsection{A ação dos predadores}

Na Flórida, Browing e Peña (1995) observaram, em estudos preliminares, que Chrysoperla rufilabris (Chrysopidae) após três semanas de liberação, reduziu a população de $P$. citrella e que Chrysopa bonensis, em seu estágio de larva, alimentou-se de 149 lagartas do minador durante seu desenvolvimento. Os autores também relataram a ação de formigas, aranhas, tripes e percevejos como predadores das lagartas do minador. Entretanto, chamaram a atenção de que para o sucesso de programas de controle, haveria a necessidade de liberações, para aumentar suas populações no campo.

Peña (1996) observou a ação de vários predadores como Chrysoperla rufilabris (Chrysopidae), Orius sp e um ácaro da família Ascidae observado em laboratório sobre ovos de $P$. citrella .

Predadores como Chrysoperla carnea Stephan (Neuroptera: Chrysopidae), Chiracanthium sp (Araneae: Clubionidae), Orius sp. (Heteroptera: Formicidae) foram observados alimentando-se freqüentemente de lagartas de $P$. citrella, principalmente quando havia a presença de afideos nos pomares da Espanha. Estes predadores e a maioria dos parasitóides nativos generalistas, como Cirrospilus (próximo a lyncus), tiveram no entanto, preferência por lagartas de $3^{\circ}$ instar do minador, não 
atacando ovos, lagartas pequenas ou pupas (Urbaneja et al., 1999 e 1998). Este fato levou à importação de $A$. citricola, parasitóide de ovos e de lagartas de $1^{\circ}$ ínstar (Edwards \& Hoy, 1998) e G. fausta, parasitóide de pupas (LaSalle \& Peña, 1997), como prováveis parasitóides a incrementar a fauna benéfica na redução das populações de $P$. citrella na Espanha.

No Brasil, Gravena (2001) observou que a presença de formigas e vespas anulou a ação de $A$. citricola em áreas de vegetação natural altamente diversificada, com porcentagens de predação de 62 e $68 \%$, respectivamente, em duas fazendas no estado de São Paulo.

Embora a ação de predadores seja importante no controle do minador, tem sido maior a utilização de parasitóides nativos ou introduzidos pela facilidade de criação em laboratório destes organismos.

\subsection{A. citricola}

\subsubsection{Distribuição geográfica}

A. citricola foi descrito através de populações oriundas do Vietnã (Logvinovskaya, 1983), ocorrendo também em Taiwan e Tailândia (Schauff et al., 1998). Atualmente, devido à sua utilização como agente de controle de $P$. citrella, encontra-se distribuído por vários países como: Austrália, Bahamas, Grécia, Honduras, Israel, Marrocos, Oman, Síria, Tunísia, Turquia, EUA (Flórida e Louisiana) (Schauff et al., 1998), Espanha (Garijo \& Garcia, 1994; Urbaneja et al., 1998), Argentina (Willink, et al., 1998), Peru, Chile (Sacarías \& Canales, 1999) e Brasil (Sá et al., 2000; Parra et al., 2001; Gravena, 2001). 


\subsubsection{Características bioecológicas}

O parasitóide $A$. citricola, pertence à superfamília Chalcidoidea, família Encyrtidae e subfamília Encyrtinae. Esta espécie foi descrita por Logvinovskaya em 1983, através de espécimens procedentes da Republica Democrática do Vietnã, Hanói e cujo holótipo encontra-se na coleção do Zoologia do Instituto Acadêmico de Ciências da Rússia, Leningrado (Sacarías e Canales, 1999).

Os encirtídeos são poliembriônicos e todos são parasitóides de ovos e lagartas de lepidópteros de várias famílias. Os ovos destes himenópteros têm pouco vitelo, sendo deixados nos tecidos dos hospedeiros para que possam obter a maioria de seus nutrientes (Clausen ${ }^{2}$ citado por Edwards \& Hoy, 1998).

A. citricola é um microimenóptero preto brilhante de 0,5 a $1 \mathrm{~mm}$, cujas características morfológicas de fêmeas e machos são descritas respectivamente por Logvinovskaya (1983) e Evans, (1995). A separação dos sexos é facilitada pela observação dos dois primeiros segmentos antenais das fêmeas os quais, são menores quando comparados aos demais, enquanto nos machos, estes segmentos têm o mesmo tamanho (Logvinovskaya, 1983).

Logvinovskaya (1983) descreveu A. citricola como poliembriônico, e que se reproduzia por partenogênese telítoca. Em 1995, Evans observou também a existência de machos em pomares na Flórida, em insetos introduzidos da Austrália em 1994 (Edwards \& Hoy, 1998).

Edwards e Hoy (1998) observaram que a poliembrionia de $A$. citricola é um pouco diferente de outros encirtídeos, descrevendo-o com detalhes.

Durante os estudos de biologia de A. citricola, Edwards e Hoy (1998) observaram que não houve efeito da idade dos ovos de $P$. citrella nos níveis de parasitismo deste encirtídeo. Como A. citricola também parasita lagartas de $1^{\circ}$ instar,

\footnotetext{
${ }^{2}$ CLAUSEN, C. P. Entomophagous insects. New York: McGraw-Hill, 1940.
} 
este parasitóide pode ser criado em laboratório sobre ovos e lagartas pequenas do minador (Neale et al. 1995; Smith \& Hoy, 1995; Hoy \& Nguyen, 1997; Edwards \& Hoy, 1998; Sacarías e Canales, 1999).

O número de descendentes de $A$. citricola por hospedeiro é muito variável. Em condições de campo, o número de pupas varia de 1 a 4 (Hoy \& Nguyen, 1994), 1 a 8 (Hoy et al., 1997) e 1 a 9 (Willink et al., 1998). Em laboratório, também há variação, sendo que Argov e Rössler (1998) observaram um máximo de 9 e outros relataram até 10 pupas nestas condições (Logvinovskaya, 1983; Smith \& Hoy, 1995; Edwards e Hoy, 1998).

Edwards e Hoy (1998) observaram que fềmeas virgens de $A$. citricola produziram somente machos do parasitóide, enquanto fêmeas copuladas, produziram ambos os sexos, confirmando que este Encyrtidae apresenta também partenogênese arrenótoca.

A longevidade dos adultos não ultrapassa 5 dias a 25 e $30^{\circ} \mathrm{C}$ em umidade relativa de até $90 \%$ segundo Smith \& Hoy (1996) e Hoy \& Nguyen (1997), embora Smith e Hoy (1996) tenham observado 1 parasitóide vivendo até 15 dias. Argov \& Rössler (1996 e 1998) observaram que a longevidade pode variar de 1 a 7 dias a $25^{\circ} \mathrm{C}$. Edwards \& Hoy (1998), variaram a umidade relativa do ar na temperatura de $30^{\circ} \mathrm{C}$ e observaram que a maior longevidade foi de 4 dias a $96 \%$ de UR, sendo inferior a $24 \mathrm{~h}$ nas menores umidades.

Chagas $^{3}$ (citado por Parra, 2000) estudaram as exigências térmicas de $A$. citricola em laboratório, concluindo que a temperatura base $(\mathrm{Tb})$ é de $13,7^{\circ} \mathrm{C}$ e a constante térmica é de 197,7 graus dias.

\footnotetext{
${ }^{3}$ CHAGAS, M.C.M. Informação pessoal transmitida a Parra, 2000
} 


\subsubsection{A.citricola como agente de controle de $P$. citrella}

A eficiência de parasitóides de $P$. citrella, nativos ou introduzidos é variável, sendo dependente de variações climáticas (temperatura e UR) e aplicação de inseticidas. Segundo Hoy \& Nguyen (1997) os especialistas são os mais eficientes em relação aos generalistas.

Neale et al. (1995) relataram a introdução de $A$. citricola na Austrália a partir de 1990, onde após sua liberação em campo, dispersou-se por $300 \mathrm{~km}$ em três anos promovendo até 90\% de parasitismo (Hoy \& Nguyen, 1997). Esta experiência australiana, não só testou a especificidade de vários parasitóides originários da China $\mathrm{e}$ Tailândia como demonstrou a eficiência de A.citricola como agente controlador. Esta introdução pioneira, serviu de base para a posterior utilização deste Encyrtidae na Flórida (EUA), onde A. citricola foi introduzido em 1994 e mais uma vez, dispersou-se rapidamente por uma área de 860.000 acres com níveis médios de parasitismo de $80 \%$ (Hoy \& Nguyen, 1997).

A partir do modelo de criação de $A$. citricola desenvolvido na Flórida por Smith \& Hoy (1995), vários países adotaram tal técnica para o controle do minador, e cuja eficiência é relatada por vários autores (Smith e Hoy, 1995; Hoy \& Nguyen, 1997; Argov e Rössler, (1996 e 1998); Pomerinke \& Stansly, 1998; Sacarías e Canales, 1999; Urbaneja et al. (1998 e 2000); Sá et al. 2000b).

No Brasil, A. citricola foi introduzido em outubro de 1998 a partir de populações oriundas da Flórida. Em esforço conjunto, entidades públicas (ESALQ e EMBRAPA) e privadas (GRAVENA ManEcol e FUNDECITRUS) realizaram a importação e liberação deste parasitóide motivadas pelo aumento do cancro cítrico, doença que cresceu no estado de São Paulo desde a chegada de P. citrella ao Brasil (Parra et al., 2001; Gravena, 2001). O desenvolvimento de uma técnica de criação desse parasitóide adequada às condições brasileiras, com vistas à redução de mão-de-obra e espaço para sua criação, possibilitou uma produção no Laboratório de Biologia de Insetos do Departamento de Entomologia, Fitopatologia e Zoologia Agrícola, de 
aproximadamente 300.000 vespas, as quais foram liberadas em diferentes áreas representativas de produção de citros dos Estados de São Paulo, Minas Gerais, Goiás, Santa Catarina, Paraná e Rio Grande do Sul. Em 17 propriedades localizadas nas regiões norte, centro e sul do Estado de São Paulo onde $A$. citricola foi liberado, a recuperação do parasitóide foi de $88 \%$ das áreas liberadas, sendo os maiores índices de parasitismo apresentados na região sul (mais úmida) e central (Parra et al., 2001). Segundo levantamentos realizados por Gravena (2001), os índices de parasitismo variaram de 0 a $100 \%$ sendo a média crescente no período avaliado de janeiro a março de 2001 de 38 para $64,3 \%$.

Anteriormente às liberações de $A$. citricola, Costa et al. (1999) e Sá et al. (1999) realizaram levantamentos para avaliar a presença de parasitóides nativos de $P$. citrella, verificando que o Eulophidae G. fausta foi o mais abundante, correspondendo a 90 - 97\% dos insetos amostrados. Contudo, após a introdução de $A$. citricola, verificouse a sua ocorrência em $60,10 \%$ das amostras enquanto que G. fausta, em 38,30\% (Sá et al., 2000 a). A. citricola não só adaptou-se ao Estado de São Paulo, como tornou-se mais abundante que o parasitóide nativo, G. fausta (Sá et al. 2000 a). 


\section{MATERIAL E MÉTODOS}

As pesquisas foram realizadas no Laboratório de Biologia de Insetos do Departamento de Entomologia, Fitopatologia e Zoologia Agrícola da Escola Superior de Agricultura "Luiz de Queiroz" (ESALQ), da Universidade de São Paulo (USP) em Piracicaba, S. Paulo.

$\mathrm{Na}$ condução dos bioensaios, foram mantidas em laboratório, criações estoques de Phyllocnistis citrella Stainton, 1856 (Lepidoptera: Gracillariidae) e Ageniaspis citricola Logvinovskaya, 1983 (Hymenoptera: Encyrtidae).

\subsection{Criação de $P$. citrella}

Populações do minador-dos-cítros, $P$. citrella, foram mantidas em laboratório, em mudas de limão cravo (Citrus limonia L. Osbeck), fornecidas pelo Fundo Paulista de Defesa da Citricultura (FUNDECITRUS). Estas mudas constituíramse de "cavalinhos" de aproximadamente 25 a $30 \mathrm{~cm}$ de altura, plantados em tubetes pretos de material plástico de $20 \mathrm{~cm}$ de altura por $1,5 \mathrm{~cm}$ de diâmetro (Figura $1 \mathrm{~A}$ ), em substrato contendo vermiculita e composto vegetal (1:1).

As plantas de limão cravo, mantidas em tubetes, foram colocadas sobre bancadas, em casa-de-vegetação (Figuras 1B), onde sofreram podas, realizadas a 1/3 do ápice da planta. Posteriormente, as mudas foram adubadas com Miracle- Groß (15-3015 de NPK, além dos micronutrientes, boro, cobre, ferro, manganês, molibdênio e zinco), sendo acondicionadas em bandejas plásticas de $35 \times 40 \times 8 \mathrm{~cm}$, com capacidade 
para 80 plantas (Figura 1C). As mudas permaneceram imersas em solução nutritiva ( $2 \mathrm{~g}$ de adubo/2 1 de água) por 5 dias, sendo retiradas e dispostas novamente em bancadas, onde após 15 a 17 dias, surgiram as primeiras brotações, as quais, foram expostas à infestação, pelo minador, em gaiolas de criação.

As gaiolas de criação, de madeira, cúbicas com $60 \mathrm{~cm}$ de aresta, foram recobertas nas quatro laterais por tela anti-afideos, de coloração branca (Figura 1D), Para facilitar a entrada e saída de plantas dentro das mesmas, na parte frontal da gaiola, de vidro, foi instalada uma "manga", confeccionada de tecido "voil", em abertura circular de $20 \mathrm{~cm}$ de diâmetro. Na parede lateral da gaiola, uma porta de $30 \times 30 \mathrm{~cm}$, facilitou o manuseio dos "cavalinhos", os quais foram mantidos em grades de metal de $25 \times 15 \mathrm{~cm}$, com capacidade para 40 mudas.

As mudas de limão cravo em tubetes, dentro das gaiolas de criação, foram expostas à infestação do minador por 2 dias, liberando-se um casal de P.citrella para cada grupo de três plantas (1:3). Os insetos foram alimentados com pequenos "filetes" de mel puro, distribuídos na parede de vidro das gaiolas.

Após a infestação, as mudas foram vistoriadas, detectando-se a presença dos ovos, que são translúcidos, brilhantes, visíveis através de um foco de luz. Uma vez constatada a presença dos ovos nas mudas, elas foram colocadas em bandejas plásticas contendo água, e levadas para prateleiras de metal, onde ocorreu o desenvolvimento do minador. A infestação das plantas e a sua acomodação em prateleiras, foram realizadas em salas com temperatura constante de $25 \pm 2^{\circ} \mathrm{C}$, umidade relativa de $70 \pm 10 \%$ e fotofase de $14 \mathrm{~h}$, condições que permitiram o corte das folhas contendo pupas do minador dois dias antes da emergência de P.citrella, que se dá em 15 dias (Chagas, 1999).

Após a constatação das pupas do minador, estas foram coletadas, cortando-se os ramos que as continham, mantendo-os em recipientes plásticos, forrados com papel de filtro umedecido em sua base, denominados "câmaras de emergência". $\mathrm{Na}$ tampa dos recipientes, foram realizadas aberturas recobertas por tecido "voil" para permitir a aeração, pois o excesso de umidade no interior das câmaras pode ser prejudicial, uma vez que mariposas que são pequenas, poderiam ficar presas e morrer nas pequenas gotas d'água acumuladas nas paredes das câmaras. As pupas do minador 
foram mantidas em câmaras climatizadas do tipo BOD, em temperaturas variadas, para atender ao cronograma da criação.
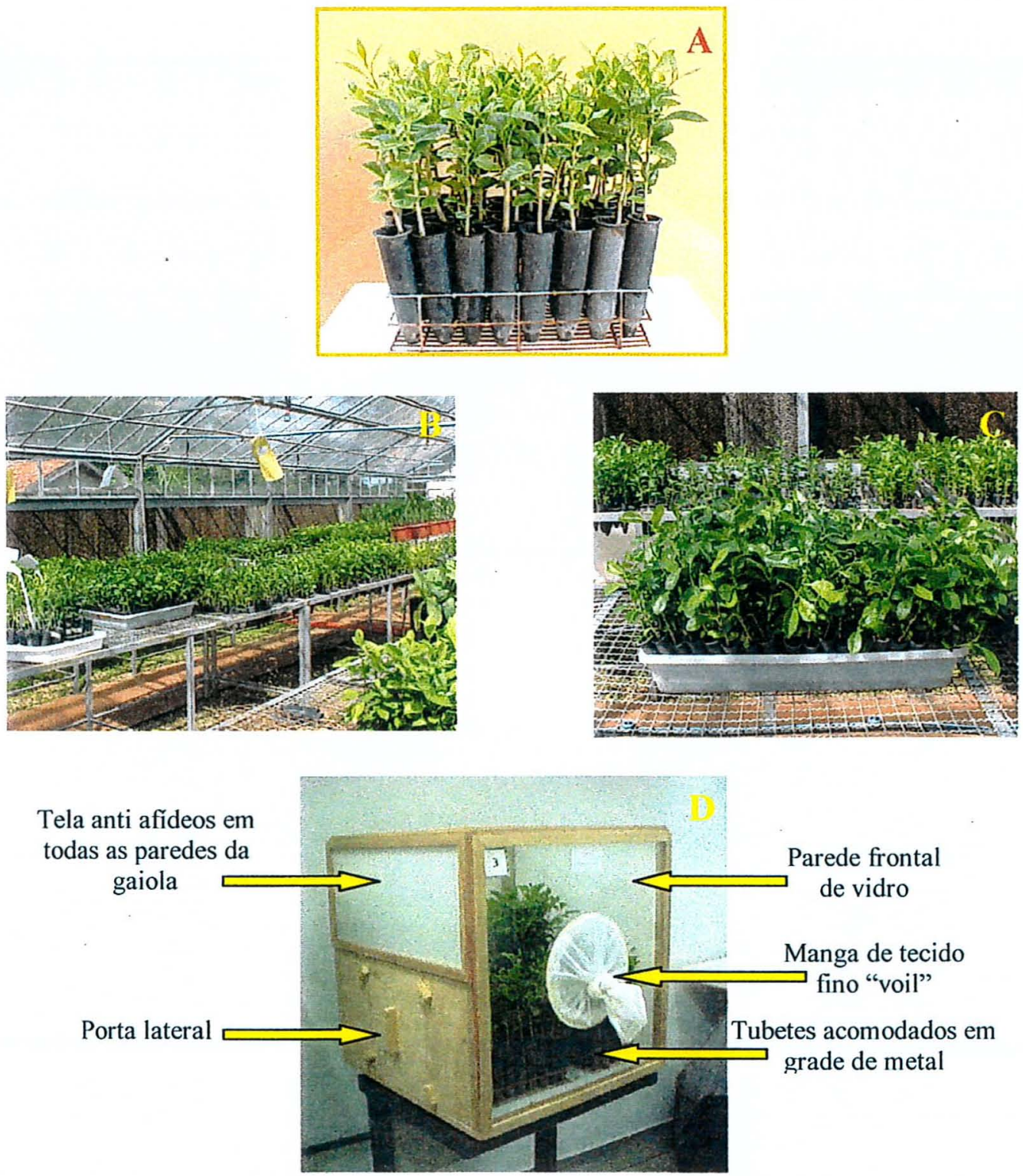

Figura 1 - Etapas da criação de P. citrella: A. Mudas de limão em tubetes; B. Tubetes em bancadas em casa-de-vegetação; C. Plantas imersas em solução nutritiva; D. Gaiola de criação. 


\subsection{Crią̧ão de $A$ citricola}

As populações de $A$. citricola foram mantidas em gaiolas semelhantes às da criação de $P$. citrella, utilizando-se o mesmo sistema de tubetes adotado para a produção de ovos, os quais foram expostos ao parasitismo por um período de 4 a 5 dias, tempo médio de vida do parasitóide. As plantas de limão cravo, contendo os ovos parasitados, permaneceram em grades de metal de $25 \times 15 \mathrm{~cm}$, imersas em bandejas plásticas com água, sendo posteriormente, acondicionadas em prateleiras de metal na sala de criação em temperatura constante de $25 \pm 2^{\circ} \mathrm{C}$, umidade relativa de $70 \pm 10 \%$ e fotofase de 14h. Nestas condições, após 14 dias, realizou-se o corte dos ramos atacados pelo minador contendo pupas de $A$. citricola ou de $P$. citrella (no caso de não terem sido parasitadas quando em sua fase de ovo ou de lagarta de $1^{\circ}$ ínstar). No $15^{\circ}$ dia, a $25^{\circ} \mathrm{C}$, obtiveram-se adultos do minador, e três dias após, adultos de $A$. citricola, os quais tiveram seu ciclo completado, na mesma temperatura, no $18^{\circ}$ dia.

Os ramos contendo as pupas, foram mantidos em recipientes plásticos semelhantes às câmaras de emergência do minador (3.1), forrados com papel de filtro umedecido.

\subsection{Otimização da criação de $A$. citricola}

\subsubsection{Número ideal de adultos de P.citrella por planta.}

A fim de se definir o número ideal de minadores nas gaiolas de criação, para maior obtenção de ovos, foi realizado um bioensaio, utilizando-se os tratamentos $\left(\mathrm{n}^{\circ}\right.$ de casais $/ \mathrm{n}^{\circ}$ de plantas) nas seguintes proporções: 1:1, 1:2, 1:3, 1:5 e 2:1.

A experimentação foi realizada em gaiolas com $29 \mathrm{~cm}$ de diâmetro por $30 \mathrm{~cm}$ de altura, com duas aberturas laterais de $20 \times 20 \mathrm{~cm}$, recobertas com tecido fino "voil" para garantir a aeração das mesmas e uma tampa, em sua parte superior, com tela anti-afideos. As gaiolas possuíam ainda, uma "manga" de voil com abertura de 10,5 cm 
de diâmetro para o manuseio das plantas testadas. Uma base de PVC, de $15 \mathrm{~cm}$ de altura, garantiu maior rigidez às gaiolas, uma vez que, o material utilizado em sua confecção foi uma lâmina plástica de poliestireno (Figura 2)

As plantas de limão cravo, em brotação, mantidas em tubetes, foram lavadas inicialmente, por um jato de água, a fim de se eliminar ácaros e/ou insetos (pulgões, moscas - brancas, etc.) uma vez que, na presença destes artrópodos, o minador não realiza a postura. Após este procedimento, as plantas foram colocadas em número de 30 cavalinhos por gaiola, para a realização dos testes.

Casais de $P$. citrella foram liberados nas proporções dos tratamentos a serem estudados. Os insetos foram alimentados com "filetes" de mel puro, distribuídos verticalmente e ao acaso, no interior das gaiolas.

$\mathrm{O}$ bioensaio foi conduzido durante $48 \mathrm{~h}$, à temperatura de $25 \pm 2{ }^{\circ} \mathrm{C}$, umidade relativa $70 \pm 10 \%$ e fotofase $14 \mathrm{~h}$, sendo realizadas cinco repetições para cada tratamento.

As plantas foram avaliadas com o auxílio de um foco luminoso para contagem do número de ovos do minador. Os resultados obtidos foram submetidos a análise de variância e, as médias, comparadas pelo teste de Tukey, ao nível de 5\% de probabilidade, sem transformação dos dados.

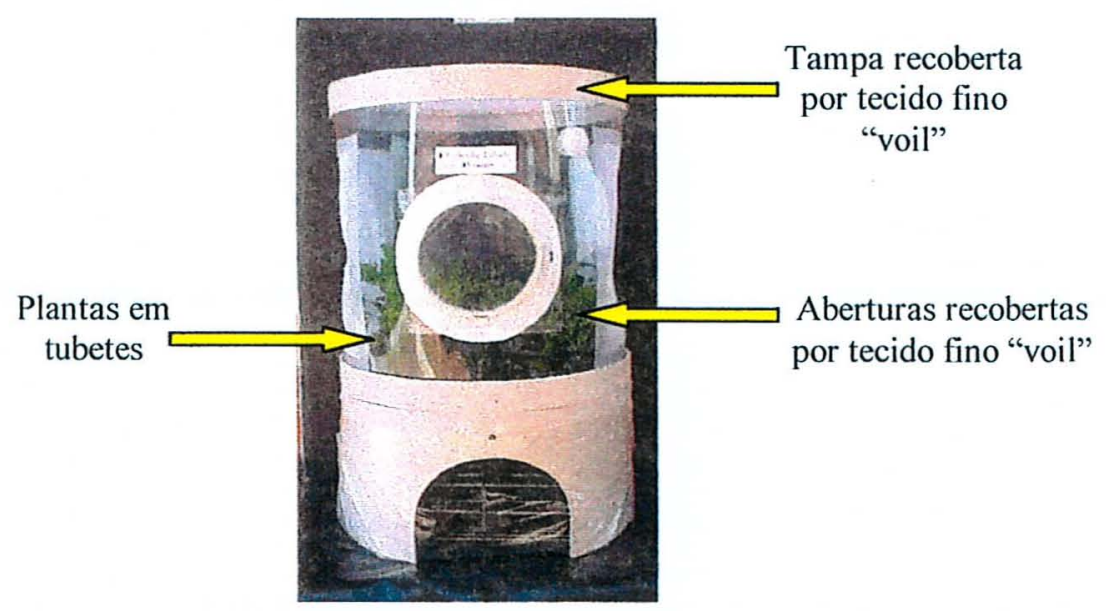

Figura 2 - Gaiola de poliestereno utilizada no bioensaio para avaliação do número ideal de adultos de $P$. citrella por planta. 


\subsubsection{Efeito do tamanho de mudas de limão cravo e número de ovos de $P$. citrella por folha de citros, na obtenção de pupas do minador}

A criação de P.citrella, com o objetivo de estabelecer a criação de $A$. citricola foi desenvolvida, em vários países, a partir de mudas com $50 \mathrm{~cm}$ de altura sendo adaptada no Brasil por Chagas (1999) o qual, utilizou mudas de limão cravo com $25 \mathrm{~cm}$ de altura, plantadas em tubetes, tanto para a criação da praga quanto do parasitóide em laboratório.

A fim de se saber qual o tamanho de plantas mais adequado para a obtenção de minadores e a partir dos resultados obtidos no teste 3.3.1(número ideal de adultos de $P$. citrella por planta em tubete), procurou-se definir o número ideal de ovos por folha para a obtenção tanto da praga como do parasitóide.

Foram testadas, mudas de limão cravo com 10 meses de idade e $60 \mathrm{~cm}$ de altura, e mudas da mesma variedade, em tubetes. As plantas em tubetes, foram mantidas em câmara climatizada mantida à temperatura de $30^{\circ} \mathrm{C}$, para que suas folhas atingissem o tamanho de 2,63 a 3,0 cm de comprimento, aproximando-se do tamanho das folhas das brotações das mudas de $60 \mathrm{~cm}$. Este procedimento não afetou a consistência das folhas que permaneceram tenras, o que não seria possível em casa-de-vegetação, pois elas seriam mais rígidas, condições desfavoráveis à oviposição (Chagas, 1999)

As mudas de limão cravo em tubetes e as mudas de $60 \mathrm{~cm}$, foram expostas à infestação por $P$. citrella, realizando-se, posteriormente, a contagem de ovos por folha mantendo-se $2,4,6,8$ e 10 ovos, sendo cada quantidade citada, um tratamento. Cada folha foi marcada por uma pequena etiqueta (Figura 3). Após a formação das câmaras pupais do minador, estas foram contadas.

$\mathrm{O}$ bioensaio foi conduzido à temperatura de $25 \pm 2^{\circ} \mathrm{C}$, umidade relativa de $70 \pm 10 \%$ e fotofase de $14 \mathrm{~h}$. em sala do laboratório de Biologia de Insetos do Departamento de Entomologia, Fitopatologia e Zoologia Agrícola. O delineamento experimental foi inteiramente casualizado, considerando-se as cinco quantidades de ovos como tratamentos e cada folha, como uma repetição, no total de 10 repetições (folhas) por tratamento. Os resultados obtidos foram submetidos à análise de variância e, as 
médias, comparadas pelo teste de Tukey, ao nível de 5\% de probabilidade, sem transformação dos dados originais.

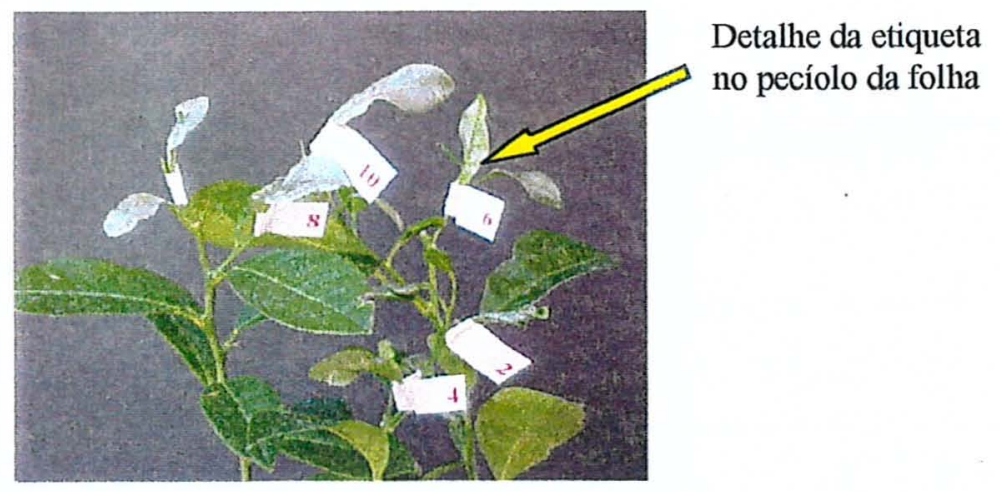

Figura 3 - Etiquetas utilizadas para a marcação de folhas no teste de efeito do tamanho de mudas e números de ovos na obtenção de pupas de $P$. citrella.

\subsubsection{Comportamento de oviposição de $\boldsymbol{P}$.citrella em diferentes variedades de citros}

Visando avaliar a oviposição de $P$. citrella em diferentes variedades cítricas, as quais, poderiam vir a ser utilizadas na produção de minadores e parasitóides, foram conduzidos testes de livre escolha e confinamento. As variedades testadas, (porta enxertos indicados pelo FUNDECITRUS), foram: limão Volkameriano, Poncirus trifoliata, Citrange Carrisa e Citromelo Swingle.

Inicialmente, foram separados 65 casais de P.citrella, uma vez que, foram utilizados 15 casais para o teste de livre escolha e 50 casais para o teste de confinamento. Os insetos, recém emergidos, foram distribuídos, em número de 16, 16, 17 e 17 casais, respectivamente, em 4 copos plásticos transparentes, de $400 \mathrm{ml}$, com $11 \mathrm{~cm}$ de comprimento. A base do copo, de $5,8 \mathrm{~cm}$ de diâmetro, recebeu duas camadas 
de papel de filtro umedecidos. Filetes de mel, foram distribuídos ao acaso, para a alimentação dos minadores. O copo, foi fechado por filme plástico da marca Magipak.

Os copos foram utilizados a fim de oferecer uma pequena área que garantisse o acasalamento e que facilitasse o trabalho de retirada dos mesmos, para a instalação dos bioensaios.

Os casais de P.citrella, ficaram confinados durante $48 \mathrm{~h}$, período suficiente para o acasalamento, sendo a seguir individualizados e, transferidos para as gaiolas de realização dos testes. O período de acasalamento, foi definido a partir de observações realizadas no laboratório de Biologia de Insetos do Departamento de Entomologia, Fitopatologia e Zoologia de Insetos.

A separação dos sexos de $P$. citrella, foi feita pela observação do final do abdome das mariposas, em microscópio estereoscópico. A fềmea, possui dois "tufos" de escamas negras, no abdome, na região do pigídeo, separando-a facilmente do macho (Chagas, 1999).

$\mathrm{O}$ teste de livre escolha, foi realizado nas mesmas gaiolas do bioensaio 3.3.1, diferindo apenas, no acréscimo de uma base, de mesmo diâmetro da gaiola, porém, com cinco aberturas circulares para a acomodação das variedades em tubetes (Figuras 4A e 4B). Foram realizadas cinco repetições em cada etapa do bioensaio, utilizando-se três casais de $P$. citrella por repetição.

$O$ teste de confinamento, foi realizado em gaiolas confeccionadas com garrafas plásticas (Chagas,1999). Estas, foram cortadas em ambas as extremidades, ficando com $23 \mathrm{~cm}$ de altura. Duas aberturas, em forma retangular de $13 \mathrm{~cm} \mathrm{X} 4 \mathrm{~cm}$, foram feitas na gaiola e recobertas com tecido fino "voil", para permitir aeração. A parte superior da gaiola, foi recoberta com "voil" e a inferior, ajustada sobre uma base de isopor, de $2 \mathrm{~cm}$ de espessura, onde, uma abertura circular foi feita para a acomodação de um tubete (Figura 4C). Um casal de P.citrella foi liberado por gaiola, em um total de dez repetições por variedade.

Os bioensaios, foram conduzidos em sala regulada à temperatura de $25 \pm 2^{\circ} \mathrm{C}$, umidade relativa de $70 \pm 10 \%$ e fotofase de $14 \mathrm{~h}$, em período de $48 \mathrm{~h}$, para os teste de livre escolha e de confinamento. 
Os ovos foram contados sob um foco luminoso e os resultados obtidos, submetidos à análise de variância e as médias comparadas pelo teste de Tukey, ao nível de $5 \%$ de probabilidade. As médias foram transformadas em $\sqrt{ }(X+1)$ para os resultados obtidos no teste de livre escolha, e log $(\mathrm{X}+1)$ para o teste de confinamento.
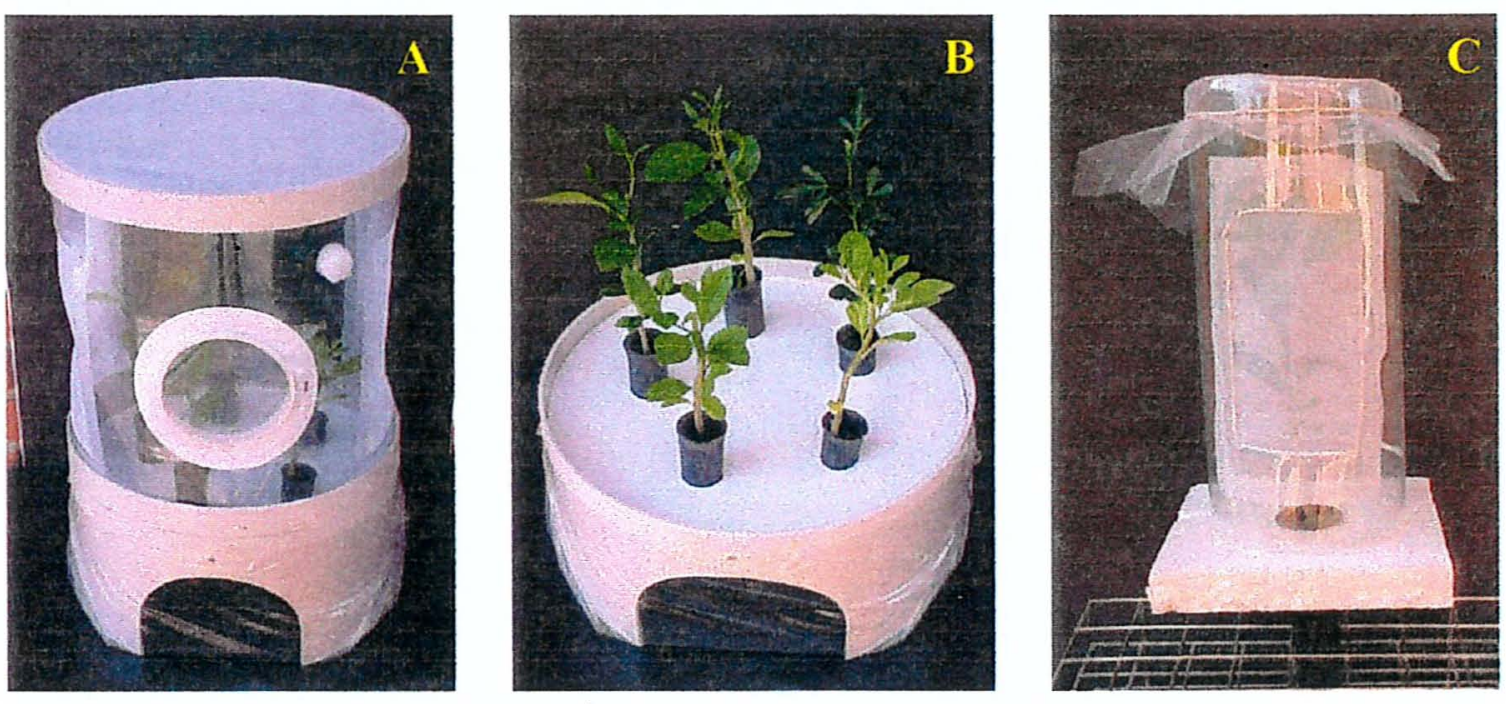

Figura 4 - Oviposição de $P$. citrella em diferentes variedades de citros. A. Gaiola utilizada no teste de livre escolha; B. Detalhe da base da gaiola para acomodação de tubetes; C. Gaiola utilizada no teste de confinamento.

\subsubsection{Parasitismo de $A$. citricola em ovos e/ou lagartas de $1^{0}$ ínstar de $P$. citrella}

Na realização do bioensaio para a determinação da preferência de $A$. citricola por ovos ou lagartas de $1^{\circ}$ ínstar de $P$. citrella, foram conduzidos testes de livre escolha e confinamento.

Inicialmente, 100 plantas de limão cravo mantidas em tubetes, foram submetidas à infestação por $P$. citrella por um período de $48 \mathrm{~h}$, e em seguida, estas plantas foram vistoriadas quanto a presença de ovos nas folhas. Ao ser constatado o número de 300 ovos, em um número de plantas que variou entre 40 a 60 , estas plantas 
foram separadas para a realização do bioensaio. O número de lagartas de $1^{\circ}$ ínstar, também foi obtido com a mesma variação no número de plantas.

No teste de livre escolha, foram expostos ao parasitismo 300 ovos e 300 lagartas de $1^{\circ}$ ínstar. Parasitóides recém emergidos, foram coletados das câmaras de emergência (3.1), com o auxilio de um tubo de $7,5 \mathrm{~cm}$ de comprimento e $1 \mathrm{~cm}$ de diâmetro, e acondicionados em uma placa de Petri de acrílico, com 6,5 de diâmetro e $2 \mathrm{~cm}$ de altura. Foram colocadas, cerca de 20 microimenópteros na placa, a qual, foi levada ao congelador por 3 minutos, para anestesiar os insetos. Após este procedimento, os insetos foram levados ao microscópio estereoscópico, para a realização da separação das fềmeas de $A$. citricola, para a instalação dos bioensaios.

A coleta de $A$. citricola, sempre foi realizada com o auxilio do pequeno tubo de ensaio, citado anteriormente, uma vez que o uso de aspirador bucal, pode causar a morte dos parasitóides, por serem eles muito sensíveis ao manuseio (Neale et al., 1995).

Trinta e três fêmeas de A.citricola, foram separadas e liberadas nas gaiolas para a realização do teste. O bioensaio, foi conduzido durante $48 \mathrm{~h}$, em gaiolas semelhantes àquelas do item 3.1. O teste de confinamento, foi realizado em $48 \mathrm{~h}$, com o mesmo número de ovos, lagartas de $1^{\circ}$ ínstar e parasitóides, descritos no teste de livre escolha. Ambos os testes, contaram com cinco repetições.

Após a realização dos testes, as plantas contendo os ovos e as lagartas de $1^{\circ}$ instar, foram acondicionadas em grades de metal, imersas em bandejas e mantidas em prateleiras, à temperatura de $25 \pm 2^{\circ} \mathrm{C}$, umidade relativa de $70 \pm 10 \%$ e fotofase de $14 \mathrm{~h}$.

No $14^{\circ}$ dia, ramos de limão cravo foram cortados, e cada câmara pupal foi aberta, observando-se a presença do parasitóide (independente do número de pupas). Os resultados obtidos, submetidos à análise de variância e as médias comparadas pelo teste de Tukey, ao nível de $5 \%$ de probabilidade. As médias foram transformadas em $\sqrt{ }(\mathrm{X}+1)$ para os resultados obtidos no teste de livre escolha e no teste de confinamento. 


\subsubsection{Influência de três temperaturas na biologia e capacidade de parasitismo de}

\section{A. citricola}

A partir de um teste preliminar em laboratório, foi definido o número de 20 ovos de $P$. citrella para serem oferecidos diariamente para a realização do teste de capacidade de parasitismo em três temperaturas. $\mathrm{O}$ teste, foi realizado à temperatura de $25 \pm 2^{\circ} \mathrm{C}$, umidade relativa de $70 \pm 10 \%$ e fotofase de $14 \mathrm{~h}$.

As gaiolas utilizadas nos bioensaios, constaram de um recipiente plástico, cilíndrico, de $9,5 \mathrm{~cm}$ de altura, cuja base menor, media $7,8 \mathrm{~cm}$ de diâmetro e a maior $9,8 \mathrm{~cm}$. Nas paredes e na base menor do recipiente, foram feitas quatro aberturas circulares, de 2,8cm de diâmetro, todas recobertas por tecido fino "voil", para permitir a aeração.

Uma tampa, com 10,5cm de diâmetro, foi acoplada à gaiola. Nesta, foi realizado um corte de raio $5,5 \mathrm{~cm}$, cuja extremidade, no centro da tampa, terminou em um pequeno círculo de $0,8 \mathrm{~cm}$ de diâmetro. Assim, a tampa pôde ser aberta e acoplada ao caule de um cavalinho de limão cravo, o qual, foi fixado à mesma, com o auxílio de pequenos pedaços de fita adesiva, que também, impediram a fuga dos insetos. A gaiola, por sua vez, foi acoplada à tampa, confinando o inseto (Figuras 5A e 5B)

O teste de capacidade de parasitismo, foi realizado em três temperaturas, $\left(20,25\right.$ e $\left.30^{\circ} \mathrm{C}\right)$ sendo, diariamente, oferecidos 20 ovos do minador a uma fềmea do parasitóide, até sua morte. $O$ delineamento experimental foi em blocos ao acaso contando com 22 repetições em cada temperatura.

Uma fêmea de A.citricola, foi colocada por gaiola, sendo os ovos de $P$. citrella, expostos ao parasitismo por $24 \mathrm{~h}$. Após este período, a fêmea do parasitóide foi recolhida em um pequeno tubo de ensaio. Com isso, as plantas puderam ser trocadas diariamente, sem que houvesse a fuga do parasitóide.

Gaiolas para a infestação de plantas por $P$. citrella, foram instaladas dia sim dia não, visando assegurar o fornecimento de ovos. Os ovos excedentes de um dia foram mantidos a $18^{\circ} \mathrm{C}$, (onde o período de incubação é de 3 dias) (Chagas, 1999; Chagas \& Parra, 2000), e utilizados no dia seguinte. Assim, foram oferecidos às fềmeas, 
em todas as repetições, nas três temperaturas, ovos com idade de 1 e 2 dias. Este procedimento, foi adotado pela dificuldade encontrada na sincronização brotação minador - parasitóide.

Os ovos de $P$. citrella, após a exposição às fềmeas de $A$. citricola, foram mantidos nas três temperaturas mencionadas $\left(20,25\right.$ e $\left.30^{\circ} \mathrm{C}\right)$. As plantas de limão cravo em tubetes, contendo os ovos, foram previamente identificados, quanto a data de parasitismo, e em seguida, imersas em bandejas com água. Com a observação de pupas do parasitóide, houve o corte dos ramos e a contagem do número de minadores parasitados, bem como o número de pupas de $A$. citricola por câmara pupal.

As folhas, contendo as pupas do parasitóide, foram colocadas em tubos de vidro de $8,5 \mathrm{~cm}$ de altura e $2,3 \mathrm{~cm}$ de diâmetro, os quais, foram mantidos nas respectivas temperaturas. Dentro dos tubos, a fim de se manter a umidade para as pupas, três retângulos de papel de filtro, de $7 \mathrm{~cm} \mathrm{X} 1 \mathrm{~cm}$, foram colocados e umedecidos com água destilada. Os tubos foram fechados por filme plástico "Magipak" e a emergência de $A$. citricola, foi registrada (Figuras 5C e 5D)
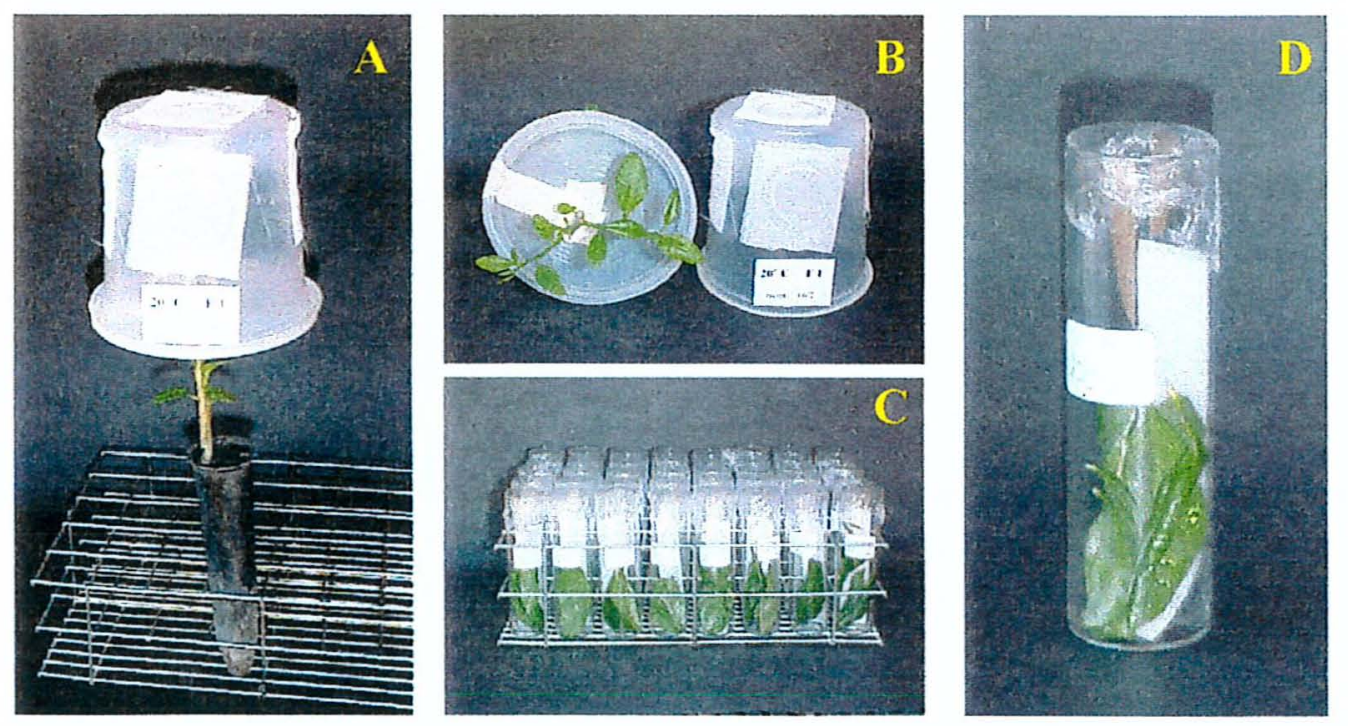

Figura 5 - Capacidade de parasitismo de A. citricola em 3 temperaturas. A. Gaiola utilizada para avaliar a capacidade de parasitismo de $A$. citricola; B. Detalhe da tampa e base da gaiola; C. Tubos de emergência de A. citricola; D. Detalhe do tubo de emergência. 
Durante este teste de capacidade de parasitismo, também foram observados: longevidade de fềmeas de $A$. citricola, viabilidade e número de pupas do parasitóide por hospedeiro e duração do período ovo - adulto nas 3 temperaturas.

Os resultados obtidos, foram submetidos à análise de variância e as médias comparadas pelo teste de Tukey, ao nivel de $5 \%$ de probabilidade. As médias

foram transformadas em $\sqrt{ }(X+1)$ para capacidade de parasitismo, longevidade das fềmeas e número de pupas por hospedeiro. Os resultados não sofreram transformações na avaliação da viabilidade pupal. A sobrevivência de $A$. citricola foi analisada pelo modelo de distribuição de Weibull (Sgrillo, 1982).

\subsection{Comparação de téenicas de liberação de $A$ citricola em campo e da idade de pupas do parasitóide a serem colocadas nestes recipientes.}

Foram comparados, dois tipos de recipientes para a liberação de $A$. citricola em campo. O primeiro, um tubete preto com $17 \mathrm{~cm}$ de comprimento e $5 \mathrm{~cm}$ de diâmetro, e o segundo, um copo plástico, de coloração branca leitosa, com $12 \mathrm{~cm}$ de comprimento por $8 \mathrm{~cm}$ de diâmetro (Figuras $6 \mathrm{~A} \mathrm{e} 6 \mathrm{~B}$ )

Ambos os recipientes, receberam duas folhas de papel de filtro umedecidos, de $5 \mathrm{~cm}$ por $11,5 \mathrm{~cm}$, além, de uma porção de algodão hidrófilo, o qual, também foi umedecido, recebendo $37,5 \mathrm{ml}$ de água, a fim de garantir a umidade para as pupas em campo. Os recipientes foram fechados por tecido fino do tipo "tule", que permitiu a saída dos parasitóides e a proteção contra possíveis predadores. Os recipientes continham alças de arame para que pudessem ser fixados em árvores (Figura 6C).

Além de se testarem os recipientes citados, três idades de pupas do parasitóide, foram observadas, ou seja, pupas do parasitóide faltando 1,2 e 3 dias para a emergência dos insetos, procurando-se observar, qual a melhor idade das pupas para ser levada ao campo. 
O delineamento experimental foi inteiramente casualizado, onde os tratamentos foram as diferentes idades das pupas nos diferentes recipientes. Dez repetições por tratamento, foram realizadas, em um total de 60 repetições instaladas em campo. Cada repetição recebeu 20 pupas do parasitóide para cada tratamento (Tabela 1)

Foram realizadas duas instalações em pomar da Escola Superior de Agricultura "Luiz de Queiroz", a partir das 17: 00h, horário de menor insolação. Os recipientes foram instalados no centro das árvores de citros, sendo que cada árvore recebeu um copo e um tubete. Três linhas de árvores foram escolhidas no centro do pomar, e para cada linha, foi destinado um tratamento (Figura 6D)

Tabela 1. Delineamento para avaliação de técnicas de liberação e observação da melhor idade de pupas de $A$. citricola no campo.

Tratamentos

\begin{tabular}{cccc}
\hline Idade das & Tubete & Copo & Número de pupas de \\
pupas & Número de repetições & A.citricola por repetição \\
1 dia & 10 & 10 & 20 \\
2 dias & 10 & 10 & 20 \\
3 dias & 10 & 10 & 20 \\
\hline
\end{tabular}

Foram realizadas observações 7 dias após a instalação dos recipientes, verificando-se a porcentagem de adultos emergidos em cada tratamento, com base nas pupas "vazias" do parasitóide. Os resultados obtidos, foram submetidos à análise de variância e as médias comparadas pelo teste de Tukey, ao nível de $5 \%$ de probabilidade sem transformação dos dados. 

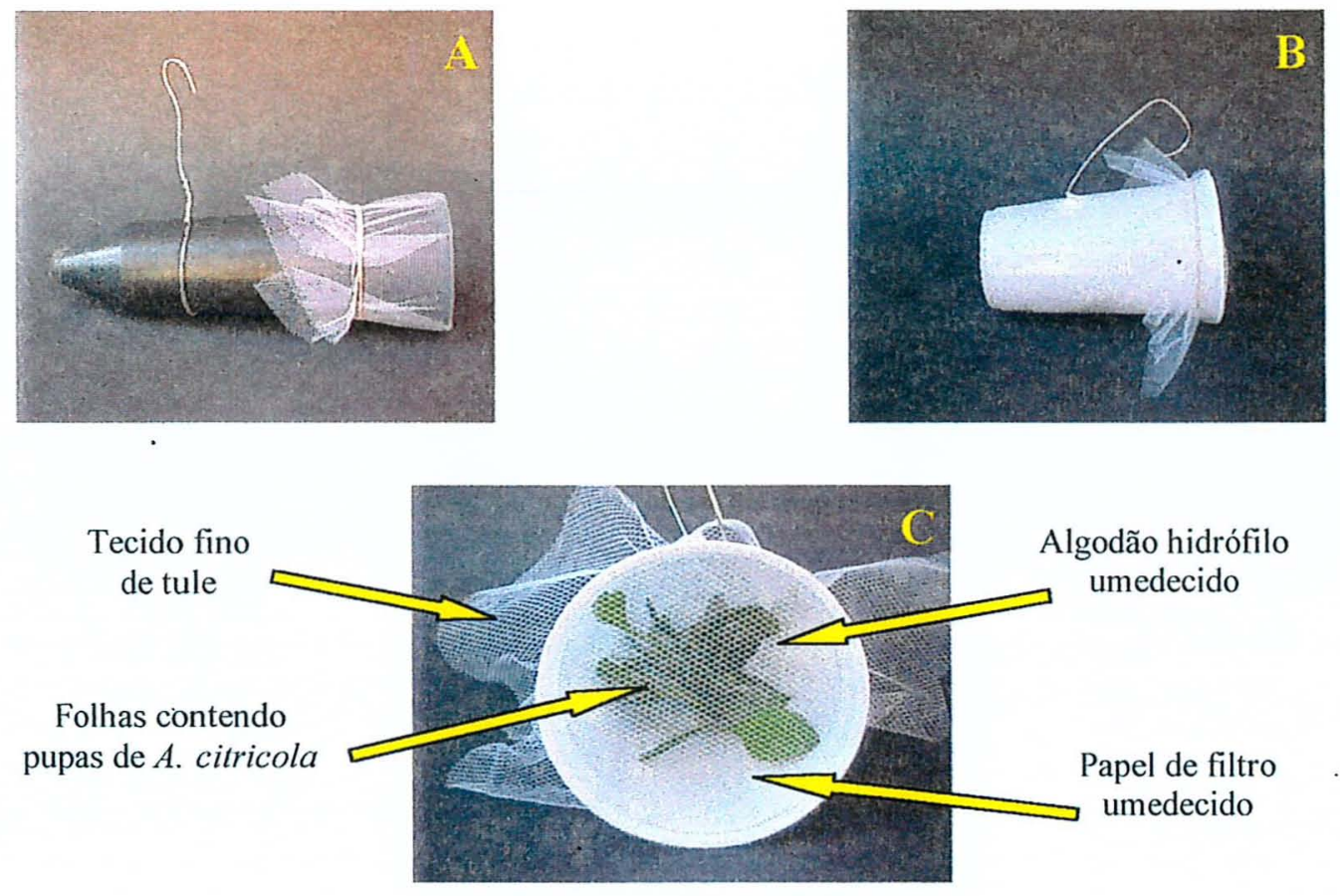

\begin{tabular}{|c|c|}
\hline 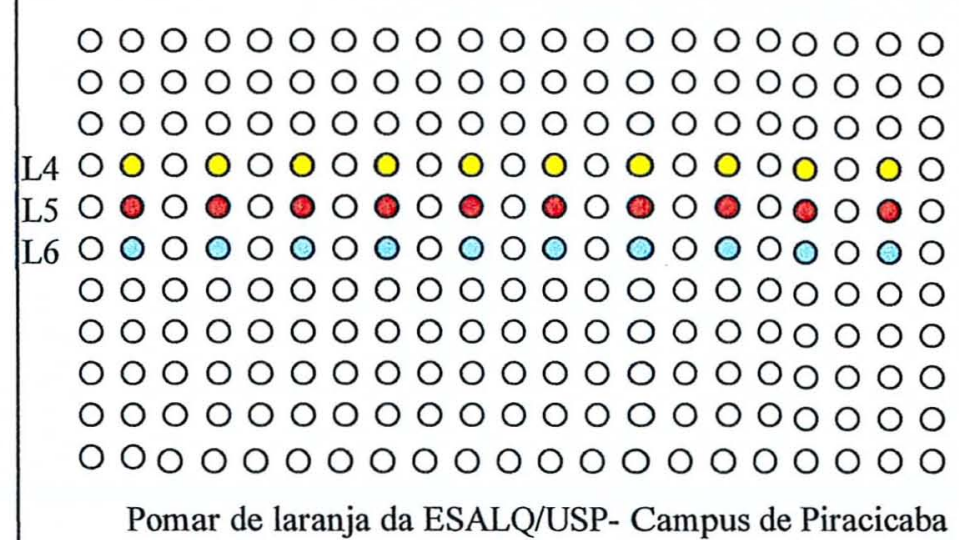 & $\begin{array}{l}\text { O } 1 \text { dia p/ emergência } \\
2 \text { dias p/ emergência } \\
3 \text { dias p/ emergência } \\
\mathrm{L}=\text { linha }\end{array}$ \\
\hline
\end{tabular}

Figura 6 - Comparação de técnicas de liberação de A. citricola em campo. A. Tubete utilizado para liberação com "voil" na extremidade; B. Copo plástico utilizado para liberação com "voil" na extremidade; C. Estrutura geral do copo com detalhes da manutenção da umidade; D. Distribuição dos tratamentos no pomar (Locais de instalação das diferentes idades de pupas de A. citricola em tubetes e copos). 
3.5 Espécies de parasitóides nativos de $P$. citrella encontrados em pomares 1 ano após o início das liberações de $\boldsymbol{A}$. citricola.

Após um ano das liberações de $A$. citricola em 16 fazendas localizadas em diferentes regiões do estado de São Paulo (Figura 7), amostras de brotações destas propriedades, foram enviadas ao Laboratório de Biologia de Insetos da ESALQ/USP, a fim de se verificar quais as espécies de parasitóides nativos de $P$. citrella, estavam presentes ocorrendo juntamente com A. citricola.

As brotações atacadas por $P$. citrella, foram mantidas em sacos plásticos, sobre uma folha de papel de filtro umedecida, com aberturas recobertas por tecido "voil", para permitir a aeração dos mesmos. Observações diárias foram realizadas, e os parasitóides nativos, recolhidos e conservados em álcool $70 \%$.

A identificação dos parasitóides, foi realizada pelo Dr. Valmir A. Costa, do Laboratório de Controle Biológico, do Centro Experimental do Instituto Biológico em Campinas, SP.

\subsection{Verificação da adaptação de $A$. citricola em pomares de citros 3 anos após sua introdução no Brasil}

Liberações de $A$. citricola foram realizadas em todo o Estado de São Paulo, a partir de outubro de 1998, após este parasitóide passar por um período de quarentena, no Laboratório Costa Lima na EMBRAPA (CNPMA), com cede em Jaguariúna, SP.

Foram selecionadas as 16 propriedades pertencentes ao grupo FISCHER S/A Agropecuária, listadas na (Figura 7) a fim de se observar a adaptação de $A$. citricola em pomares com diferentes variedades de citros e diferentes condições climáticas nas regiões norte, centro e sul do estado de São Paulo. Para tanto, amostras de brotações atacadas por $P$. citrella, foram recolhidas e enviadas ao Laboratório de Biologia de 
Insetos da ESALQ- USP, onde foram minuciosamente inspecionadas quanto à presença de pupas do parasitóide e do minador .

As amostras das brotações, foram recolhidas ao acaso, tanto em quadras onde realizaram-se as liberações do parasitóide, quanto em quadras distantes, totalizando 50 brotações por quadra. As avaliações foram realizadas no período de dezembro de 2000 e fevereiro - março.

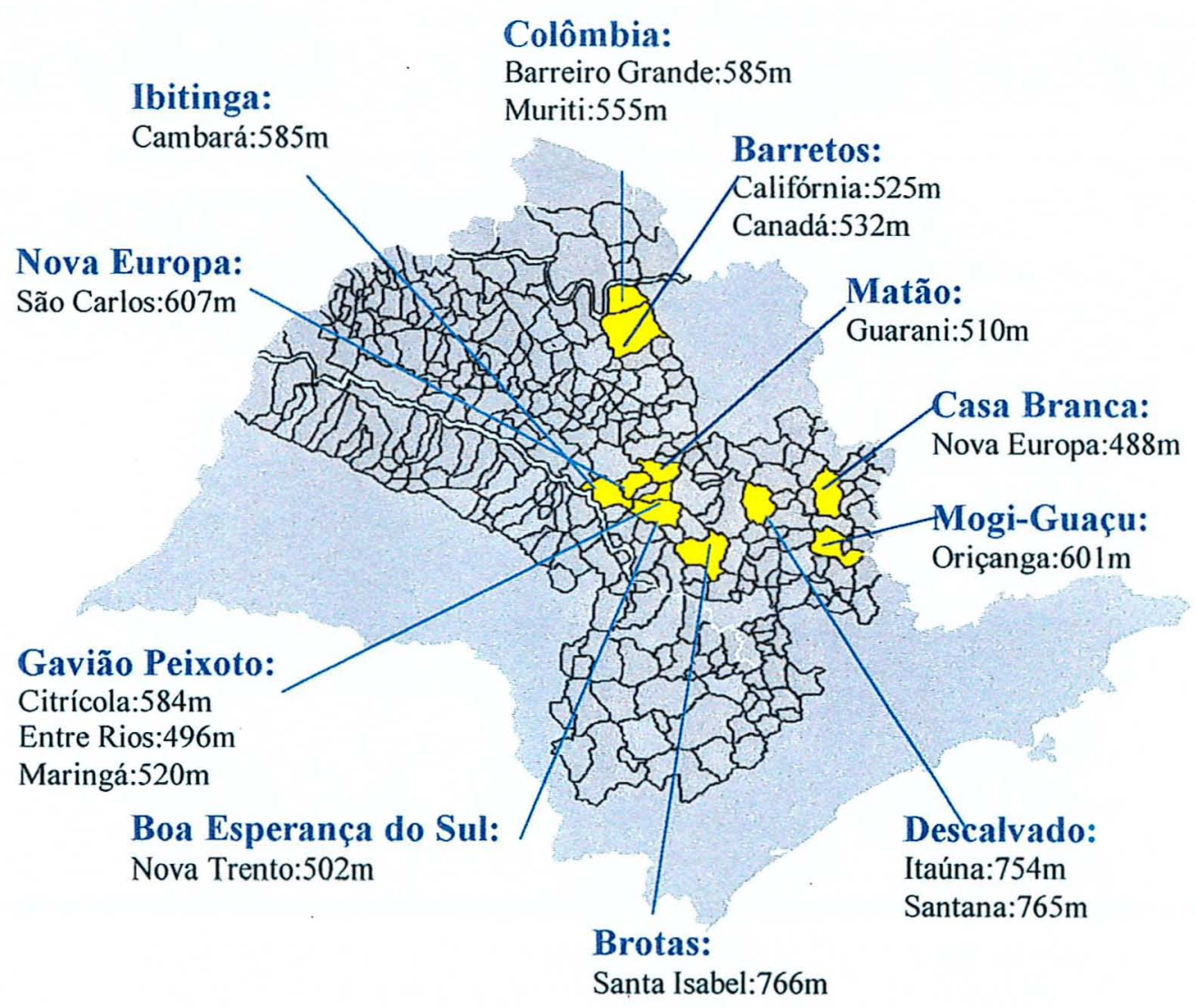

Figura 7- Altitude dos Centros de serviços baseadas em cartas geográficas do IGC,IBGE e IGA das 16 fazendas pertencentes ao grupo FISCHER S/A-Agropecuária onde foram realizadas as amostragens da porcentagem de parasitismo de $A$ citricola. 


\section{RESULTADOS E DISCUSSÃO}

\subsection{Otimização da criação de Ageniaspis citricola Logvinovskaya, 1983}

\subsubsection{Número ideal de adultos Phyllocnistis citrella Stainton, 1856 por planta}

Observou-se que a proporção mais adequada foi a de dois casais de $P$. citrella para cada planta $(2: 1)$, pois nesta situação foi obtido o maior número de ovos durante $48 \mathrm{~h}$, sendo a relação menos adequada a de 1:5 (Tabela 2).

Tabela 2. Número total de ovos de $P$. citrella/planta e número médio de ovos/folha, em limão cravo mantido em tubetes. Temperatura $25 \pm 2^{\circ} \mathrm{C}$, UR: $70 \pm 10 \%$ e fotofase $14 \mathrm{~h}$.

\begin{tabular}{cccc}
\hline $\begin{array}{c}\text { Tratamentos } \\
P . \text { citrella: } \text { planta }\end{array}$ & $\mathrm{N}^{2}$ & $\mathrm{n}^{0}$ total de ovos & $\mathrm{n}^{0}$ médio de ovos/folha \\
\hline $2: 1$ & 30 & $607,00 \pm 53,05 \mathrm{a}$ & $3,37 \pm 0,17 \mathrm{a}$ \\
$1: 1$ & 30 & $273,80 \pm 31,66 \mathrm{~b}$ & $1,66 \pm 0,23 \mathrm{~b}$ \\
$1: 2$ & 30 & $164,20 \pm 25,92 \mathrm{bc}$ & $0,97 \pm 0,15 \mathrm{bc}$ \\
$1: 3$ & 30 & $100,40 \pm 5,25 \mathrm{c}$ & $0,57 \pm 0,05 \mathrm{c}$ \\
$1: 5$ & 30 & $42,20 \pm 11,11 \mathrm{c}$ & $0,27 \pm 0,06 \mathrm{c}$ \\
\hline
\end{tabular}

\footnotetext{
${ }^{\mathrm{T}}$ Médias seguidas por letras distintas diferem entre si, pelo teste de Tukey, ao nivel de $5 \%$ de probabilidade; dados não transformados.

${ }^{2}$ Número de plantas
} 
Portanto, fica muito claro que para criações de laboratório deve ser utilizada, em gaiolas de criação, a proporção de 2 casais de $P$. citrella por planta de citros mantida em tubetes. Neste caso chega a se obter de 3 a 4 ovos/folha (Tabela 2).

Aparentemente, não se conseguiriam melhores resultados aumentando-se a proporção além de 2 casais de $P$. citrella por planta (Tabela 2), pois o número de ovos por folha já foi alto (4.1.2, Tabela 4). Como as plantas mantidas em tubetes são pequenas, provavelmente, não haveria mais espaço para ovos. Entretanto, sugerem-se pesquisas neste sentido. Para a criação em mudas com $60 \mathrm{~cm}$, técnica utilizada por muitos pesquisadores (Neale et al., 1995; Smith \& Hoy, 1995; Argov \& Rössler, 1996 e 1998; Sacarías \& Canales, 1999), talvez fossem conseguidos melhores resultados com mais casais por planta, desde que a superfície foliar, neste caso, é maior.

\subsubsection{Efeito do tamanho de mudas de limão cravo e número de ovos de $P$. citrella por folha de citros, na obtenção de pupas do minador.}

Como era de se esperar, obteve-se a maior porcentagem de pupas nas mudas de 10 meses, em relação aos tubetes, pelo maior volume de folhas existentes no $1^{\circ}$ caso (Tabela 3). Entretanto, em ambos os casos obteve-se o maior número de pupas a partir de 2 ovos por folha e com uma porcentagem de $96 \%$ de pupas (Tabela 4 e Figura8).

A criação de $P$. citrella em vários países foi adaptada do modelo desenvolvido na Flórida (EUA), (Smith \& Hoy, 1995) no qual plantas com cerca de 30 a $50 \mathrm{~cm}$ de altura foram utilizadas para manter as populações tanto do minador, quanto dos parasitóides.

No Brasil, no Laboratório de Biologia de Insetos da ESALQ/USP, as populações de $P$. citrella e de $A$. citricola, têm sido mantidas em mudas de limão cravo cultivadas em tubetes, utilizando o sistema de criação do minador idealizado por Chagas (1999). Este sistema, em função do menor tamanho das plantas produz menos minadores do que as mudas de 10 meses. Entretanto, tais criações de P. citrella e A.citricola em 
países como Austrália, EUA, Israel e Peru, exige muito espaço, tanto para a manutenção das plantas quanto para as gaiolas de criação, as quais são mantidas em estufas ou casas de vegetação (Neale et al., 1995; Smith \& Hoy, 1995; Argov \& Rössler, 1996; Sacarías \& Canales, 1999). A grande vantagem do sistema de criação em tubetes é a economia de espaço, ao lado de grande redução de mão-de-obra e com apenas $18 \%$ de pupas a menos em relação ao sistema de mudas (Tabela 3).

Assim, o sistema de criação em tubetes, exige apenas duas salas de $3,50 \mathrm{~m}$ x 2,30m e de $2,80 \mathrm{~m} \times 2,50 \mathrm{~m}$, sendo que uma delas é para manutenção de gaiolas de infestação e parasitismo e a outra, para plantas contendo $P$. citrella parasitadas ou não, imersas em bandejas com água e colocadas em prateleiras. Ambas as instalações devem ser mantidas com temperatura e umidade controladas. $O$ sistema exige ainda, uma casade-vegetação para a manutenção das plantas. São necessárias 3 pessoas para a manutenção deste sistema em laboratório, enquanto que no Peru, são necessárias 15 pessoas entre profissionais, técnicos e auxiliares (Sacarías \& Canales, 1999) para a produção de número equivalente de parasitóides, ou seja, 5 vezes mais mão-de-obra de que o sistema idealizado em Piracicaba, SP.

Com esta economia de espaço e mão-de-obra, foi possível, no Brasil, a produção de 300.000 parasitóides no período de outubro de 1998, época da importação do parasitóide, a agosto de 2001. Deste total, $80 \%$ foi utilizado para liberação e $20 \%$ para a continuidade da criação.

Tabela 3. Porcentagem de pupas de $P$. citrella em diferentes tamanhos de mudas de limão cravo. Temperatura $25 \pm 2^{\circ} \mathrm{C}$, UR: $70 \pm 10 \%$ e fotofase $14 \mathrm{~h}$.

\begin{tabular}{cc}
\hline Tamanho de Mudas & Porcentagem média de pupa de $P$. citrella \\
\hline Mudas com 10 meses & $78,83 \pm 4,60 \mathrm{a}$ \\
Mudas em tubetes & $60,35 \pm 4,30 \mathrm{~b}$ \\
$\begin{array}{c}\text { Tédias seguidas por letras distintas diferem entre si, pelo teste de Tukey, ao nível de } 5 \% \text { de } \\
\text { probabilidade; dados não transformados }\end{array}$
\end{tabular}


Na criação de $P$. citrella desenvolvida no Laboratório de Biologia de Insetos da ESALQ/USP, uma média de 3 ovos por folha tem sido obtida em plantas de limão cravo em tubetes, utilizando-se mais de 100 insetos (sem separação de sexos), em cada gaiola de infestação, contendo até 240 tubetes e com UR de $80 \%$. Portanto, a partir dos resultados obtidos, tal metodologia de criação poderá ser melhorada, obtendo-se maior rendimento da criação a partir de 2 ovos por folha.

Smith \& Hoy (1995) mantiveram a criação de $P$. citrella em estufas com temperatura média de $30^{\circ} \mathrm{C}$ e UR de 80 a $90 \%$, utilizando de 60 a 70 plantas com 30 a $50 \mathrm{~cm}$ de altura para um número de minadores que variou de 175 a 250 insetos sem separação de sexo. Estes autores obtiveram uma média de 2,8 a 1,8 pupas de minadores por folha, registrando o caso de uma folha com até 13 pupas, fato que pôde também ser observado, nas mudas de 10 meses de idade, durante a execução do presente ensaio.

Tabela 4. Porcentagem de pupas de $P$. citrella a partir de diferentes números de ovos por folha de limão cravo em condição de laboratório em mudas de 10 meses e em tubetes. Temperatura $25 \pm 2^{\circ} \mathrm{C}$, UR: $70 \pm 10 \%$ e fotofase $14 \mathrm{~h}$.

\begin{tabular}{cc}
\hline Número de ovos/folha & Pupas $(\%)^{\top}$ \\
\hline 2 & $96,25 \pm 2,63 \mathrm{a}$ \\
4 & $75,62 \pm 6,12 \mathrm{~b}$ \\
6 & $64,31 \pm 7,05 \mathrm{bc}$ \\
8 & $58,44 \pm 7,36 \mathrm{bc}$ \\
10 & $53,32 \pm 4,80 \mathrm{c}$
\end{tabular}

T'Médias seguidas de mesma letra na vertical não diferem entre si, pelo teste de Tukey, ao nível de 5\% de probabilidade; dados não transformados

Em condições de campo, pode-se verificar o desenvolvimento de até 9 a 20 minas/folha (Hutson \& Pinto, 1934; Pandey \& Pandey, 1964; Heppner, 1993). Garcia \& Garcia (1994) observaram, na Espanha, até 28 ovos em uma folha, embora sem relatar as porcentagens de pupas originadas. Houve na presente pesquisa correlação entre o número de ovos e porcentagem de pupas formadas, sendo decrescente tal porcentagem a partir de 2 ovos/folha (Figura 8 ). 


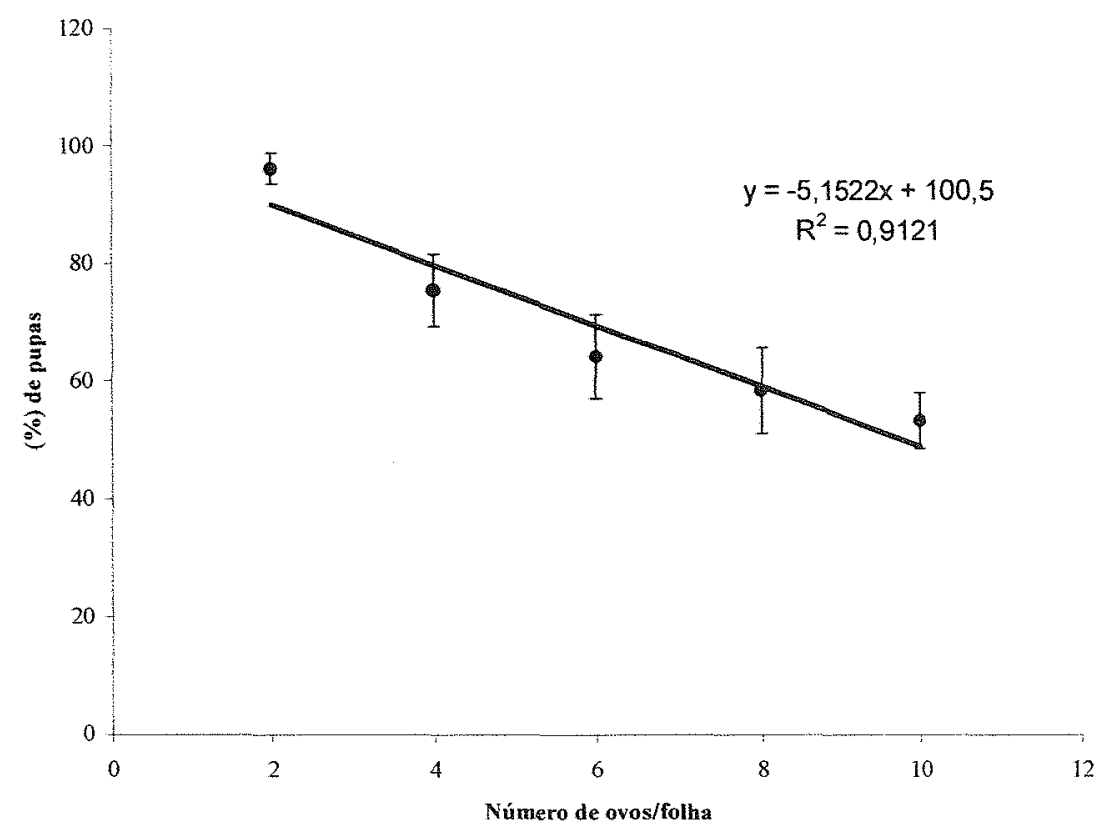

Figura 8 - Correlação entre o número de ovos por folha colocados por $P$. citrella e porcentagem de pupas formadas. Temperatura $25 \pm 2^{\circ} \mathrm{C}$, UR: $70 \pm 10 \%$ e fotofase $14 \mathrm{~h}$.

4.1.3. Comportamento de oviposição de $P$. citrello em diferentes variedades de citros

Muitas são as variedades cítricas hospedeiras de $P$. citrella (Heppner, 1993) dentre as quais, algumas têm sido utilizadas para criação em laboratório tais como: limão rugoso (Citrus lemon) (Neale et al., 1995; Argov e Rössler, 1998; Sacarías e Canales, 1999); limão (Citrus jambihiri), "grapefruit" (Citrus paradisi), laranjas (Citrus trifoliata), Swingle (Citrus aurantiifolia) e laranjas ácidas (Smith \& Hoy, 1995); limão Volkameriano (Citrus volkameriana) e lima Rangpoor ( Argov e Rössler, 1998); Cleópatra (Citrus reticulata), Sunki (Citrus sunki), laranja trifoliada (Poncirus trifoliata) (Sacarías e Canales, 1999) e limão cravo (Citrus limonia) (Chagas, 1999 e 2000). 
Observou-se, em teste de livre escolha, a preferência de $P$. citrella pelo limão Volkameriano em relação às outras variedades, com média de $10,80 \pm 6,06$ ovos por planta de (Tabela 5 e Figura 9). Em teste realizado na Flórida, EUA, juntamente com 35 outras variedades do germoplasma de Homestead (Flórida), esta variedade, no entanto, não foi atacada segundo Peña \& Duncan (1993).

Tabela 5. Média de ovos de $P$. citrella, em diferentes variedades de citros, em teste de livre escolha e confinamento durante $48 \mathrm{~h}$. Temperatura $25 \pm 2^{\circ} \mathrm{C}$, UR: $70 \pm 10 \%$ e fotofase $14 \mathrm{~h}$.

Variedades

\section{Média de ovos/planta}

Teste de Livre escolha ${ }^{1,2}$ Teste de Confinamento ${ }^{1,3}$

\begin{tabular}{lcc}
\hline limão Volkameriano & $10,80 \pm 6,60 \mathrm{a}$ & $8,70 \pm 2,68 \mathrm{a}$ \\
Citrange Carrisa & $3,80 \pm 1,16 \mathrm{ab}$ & $3,63 \pm 1,48 \mathrm{a}$ \\
limão cravo (Testemunha) & $3,40 \pm 1,44 \mathrm{ab}$ & $7,80 \pm 2,34 \mathrm{a}$ \\
Citromelo Swingle & $1,20 \pm 0,97 \mathrm{ab}$ & $5,60 \pm 1,11 \mathrm{a}$ \\
Poncirus trifoliata & $0,20 \pm 0,20 \mathrm{~b}$ & $6,22 \pm 3,57 \mathrm{a}$
\end{tabular}

Tédia seguidas de mesma letra na vertical não diferem entre si, pelo teste de Tukey, ao nível de $5 \%$ de probabilidade.

${ }^{2}$ Dados transformados para $\sqrt{ }(x+1)$

${ }^{3}$ Dados transformados para $\log (x+1)$

O teste de livre escolha foi mais discriminatório do que o teste de confinamento. Embora tenha havido diferenças apenas entre o limão Volkameriano e $P$. trifoliata, a diferença numérica foi muito grande, pois o inseto colocou apenas 3,40\% na testemunha em relação ao limão Volkameriano (Tabela 5 e Figura 9).

No teste de confinamento não houve diferença estatística entre as variedades, embora numericamente a mesma tendência do teste de livre escolha tenha sido mantida com relação ao limão Volkameriano (Tabela 5 e Figura 9).

Portanto, o comportamento do minador é muito variável com relação às variedades. Assim, segundo Peña \& Duncan (1993), a variedade Swingle ( $C$. aurantifolia ) não foi atacada, quando comparada às outras 35 variedades observadas na Flórida. Garijo Alba \& Garcia Garcia (1994) observaram que $P$. citrella atacou todas 
as variedades cítricas na Espanha, ocorrendo em menor porcentagem em laranja trifoliada ( $P$. trifoliata).

Os dados obtidos em vários trabalhos corroboram com a afirmação de que $P$. citrella prefere outras variedades de citros do que as $P$. trifoliata embora, em determinadas situações, registros de oviposição do minador ocorram nestas variedades (Tabela 5 e Figura 9). A susceptibilidade das variedades cítricas ao ataque de $P$. citrella, parece estar relacionada à espessura e consistência das folha, dureza da cutícula (Latif \& Yunus, 1951), tamanho das folhas, estrutura da cutícula e quantidade de estômatos (Zhang et al., 1994). Variedades que brotam com maior freqüência, como os limões, têm mais chances de serem atacadas. Portanto, dependendo das variedades presentes em um pomar, pode haver diferenças de ataque de $P$. citrella, assim como tal ataque pode depender da época de brotação de cada uma delas.

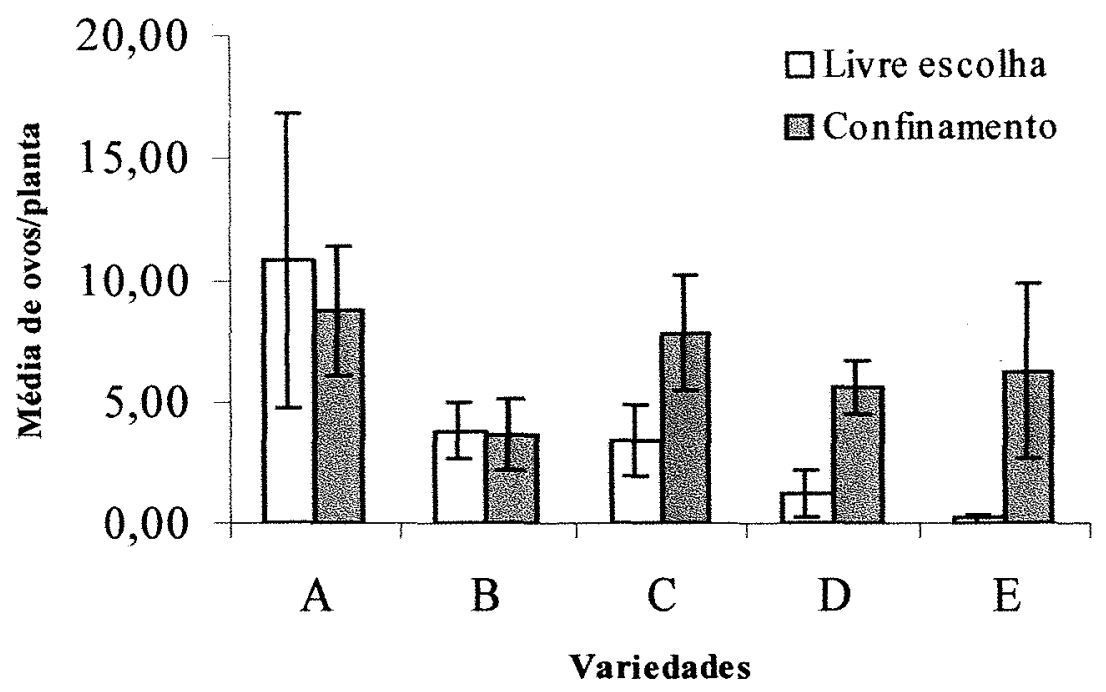

Figura 9 - Média de ovos de $P$. citrella, em diferente variedades de citros, em teste de livre escolha e confinamento. Tratamentos; A: 1. Volkameriano, B: C. Carrisa, C: 1 . cravo, D: C. Swingle, E: $P$. trifoliata. Temperatura $25 \pm 2^{\circ}$ C, UR: $70 \pm 10 \%$ e fotofase $14 \mathrm{~h}$. 


\subsubsection{Parasitismo de $A$. citricola em ovos e/ou lagartas de $1^{0}$ ínstar de $P$. citrella}

No teste de livre escolha, os resultados do parasitismo foram muito próximos, embora numericamente os ovos tenham sido mais parasitados (Tabela $6 \mathrm{e}$ Figura 10). No teste de confinamento, as lagartas de $1^{\circ}$ ínstar foram numericamente mais parasitadas embora estatisticamente, não tenham diferido dos resultados de ovos parasitados (Tabela 6 e Figura 10). Em ambos os casos, o número de pupas resultantes do parasitismo, variou de 1 a 6 , sem diferença dependente de estágio (ovo ou lagarta de $1^{\circ}$ ínstar).

Tabela 6. Parasitismo de $A$. citricola em ovos e/ou lagartas de $1^{\circ}$ ínstar de $P$. citrella medida pela formação de pupas (independente do número) em teste de livre escolha e confinamento durante $48 \mathrm{~h}$. Temperatura $25 \pm 2^{\circ} \mathrm{C}$, UR: $70 \pm 10 \%$ e fotofase $14 \mathrm{~h}$.

\begin{tabular}{lcccc}
\hline \multicolumn{3}{c}{ Livre escolha $^{1,2}$} & \multicolumn{3}{c}{ Confinamento } \\
\hline & ovos & $1^{0}$ ínstar & ovos & $1^{0}$ ínstar \\
$\%$ média & $19,27 \pm 11,01$ a & $16,22 \pm 7,47$ a & $29,63 \pm 13,14$ a & $34,53 \pm 12,54$ a \\
$\mathrm{n}^{0}$ médio & 59,6 & 49,6 & 90,8 & 105 \\
\hline
\end{tabular}

Tédias seguidas de mesma letra, na horizontal, não diferem entre si ao nível de $5 \%$ de probabilidade ${ }^{2}$ Dados transformados para $\sqrt{ }(x+1)$ para $\%$ média de ovos

A criação de $A$. citricola tem sido realizada no mundo, oferecendo-se ovos ou lagartas de $1^{\circ}$ ínstar de P. citrella (Neale et al., 1995; Smith \& Hoy, 1995; Hoy \& Nguyen, 1997, Edwards \& Hoy, 1998; Sacarías e Canales, 1999). Edwards \& Hoy (1998) observaram que a idade dos ovos de $P$. citrella, não interferiu na capacidade de parasitismo de $A$. citricola, afirmando que ovos mais velhos, são mais favoráveis ao parasitismo. Este tipo de estudo não foi realizado na presente pesquisa, sugerindo-se estudos nesta direção.

Por outro lado, na presente pesquisa foram oferecidas à $A$. citricola, lagartas de $2^{\circ}$ ínstar de $P$. citrella em testes realizados em laboratório, observando-se, 
que neste estágio de desenvolvimento larval, o minador não é parasitado (MILANO, P. observação pessoal) concordando com Edwards \& Hoy (1998) que ofereceram a $A$. citricola lagartas do minador de 2 e $3^{\circ}$ instares e não obtiveram parasitismo.

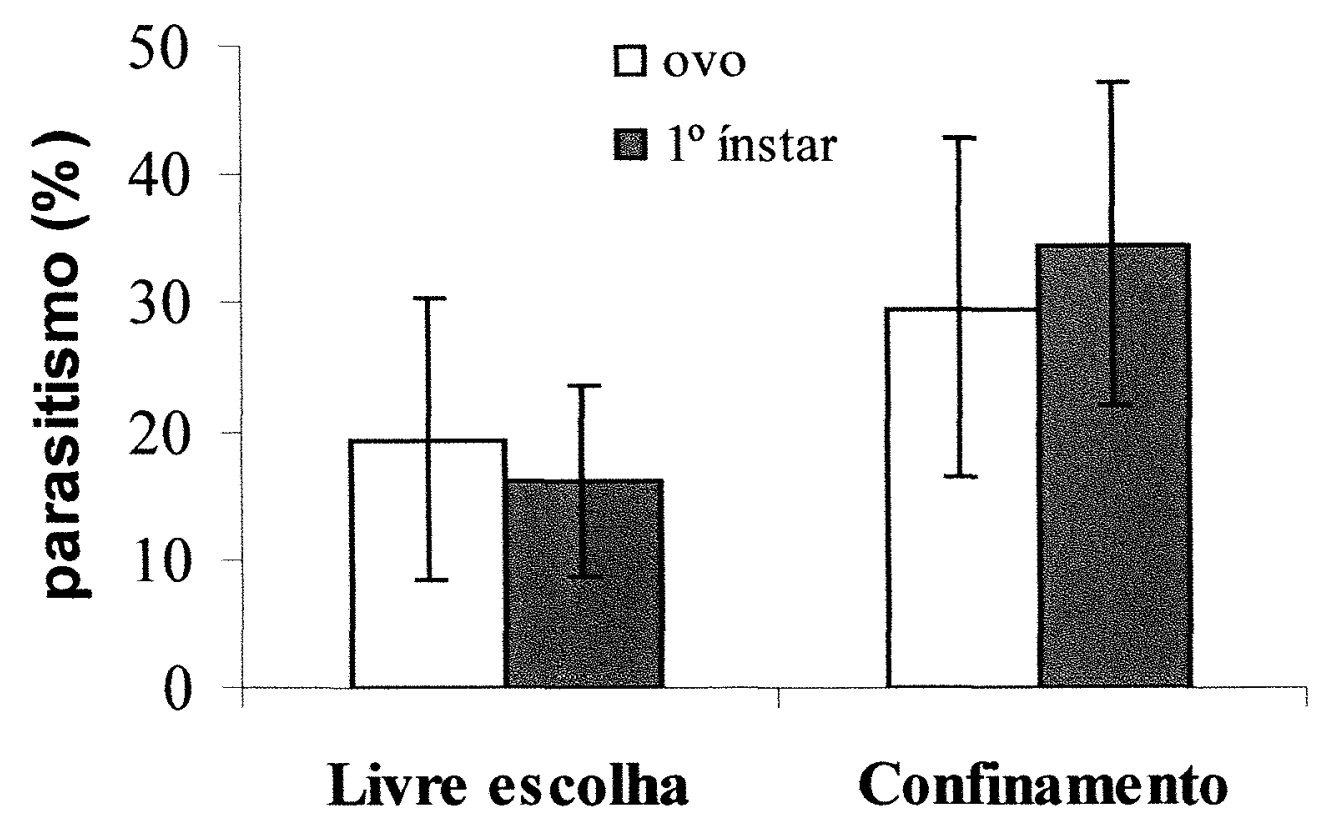

Figura 10 - Porcentagem de parasitismo de ovos e lagartas de $1^{\circ}$ ínstar de $P$. citrella por A. citricola em teste de livre escolha e confinamento. Temperatura $25 \pm 2^{\circ} \mathrm{C}$, UR: $70 \pm 10 \%$ e fotofase $14 \mathrm{~h}$.

Pôde-se constatar que o parasitismo médio foi baixo, tanto sobre os ovos $(19,27 \pm 11,01$ e $29,63 \pm 13,14 \%)$ como sobre lagartas de $1^{\circ}$ instar $(16,22 \pm 7,47$ e $34,53 \pm 12,54 \%$ ) para teste de livre escolha e confinamento respectivamente, tendo em vista o número de ovos oferecidos (300/repetição). Este baixo parasitismo pode ter sido consequência de um não parasitismo inicial ou mortalidade durante o desenvolvimento, fatos não observados na presente pesquisa. Como o parasitismo foi semelhante, tanto ovos quanto lagartas de $1^{\circ}$ ínstar podem ser oferecidos ao parasitóide, o que facilita a criação, pois se não houver disponibilidade de adultos de $A$. citricola quando existir 
apenas ovos, pode-se esperar até o desenvolvimento embrionário e a eclosão das lagartas para a obtenção de parasitismo. Por outro lado, devido ao baixo parasitismo observado, fica evidente também a dificuldade em se realizar uma produção massal desta espécie.

\subsubsection{Influência de três temperaturas na biologia e capacidade de parasitismo, de A. citricola}

\subsubsection{Capacidade de parasitismo e longevidade de fêmeas de $A$. citricola}

A capacidade média de parasitismo de $A$. citricola a 20,25 e $30^{\circ} \mathrm{C}$ não diferiu, estatisticamente entre si, variando de 20,21 à $26,01 \%$ nos valores extremos testados, respectivamente (Tabela 7).

Tabela 7. Porcentagem média de parasitismo de A. citricola e longevidade média das fêmeas em três temperaturas, UR: $70 \pm 10 \% \mathrm{e}$ fotofase $14 \mathrm{~h}$.

\begin{tabular}{ccc}
\hline Temperatura & $\begin{array}{c}\text { \% média de parasitismo } \\
\text { de } \text { A. citricola }^{1}\end{array}$ & $\begin{array}{c}\text { Longevidade média } \\
\text { das fềmeas (dias) }^{1,2}\end{array}$ \\
\hline $20^{\circ} \mathrm{C}$ & $20,21 \pm 1,80 \mathrm{a}$ & $7,83 \pm 1,80 \mathrm{a}$ \\
$25^{\circ} \mathrm{C}$ & $22,45 \pm 1,85 \mathrm{a}$ & $8,50 \pm 1,05 \mathrm{a}$ \\
$30^{\circ} \mathrm{C}$ & $26,02 \pm 2,23 \mathrm{a}$ & $5,45 \pm 0,44 \mathrm{a}$
\end{tabular}

${ }^{\top}$ Médias seguidas de mesma letra na vertical não diferem entre si, pelo teste de Tukey, ao nível de $5 \%$ de probabilidade.

${ }^{2}$ Dados transformados para $\sqrt{ }(x+1)$

A longevidade média das fềmeas de $A$. citricola, expostas às temperaturas de 20,25 e $30^{\circ} \mathrm{C}$, não diferiu estatisticamente, embora numericamente tenham sido maiores à 20 e $25^{\circ} \mathrm{C}$ (Tabela 7$)$.

A longevidade média de $A$. citricola a $25^{\circ} \mathrm{C}$ foi superior àquela encontrada por Smith e Hoy (1996) e por Argov \& Rössler (1996 e 1998), o mesmo ocorrendo em relação à temperatura de $30^{\circ} \mathrm{C}$, onde a longevidade média foi superior àquela encontrada por Hoy \& Nguyen (1997) e Edwards \& Hoy (1998). Estes últimos 
autores observaram nesta temperatura e em umidades de $96,80,63$ e 30\%, uma máxima longevidade de 4 dias em UR de $96 \%$ e longevidade menor do que $24 \mathrm{~h}$ em umidades inferiores.

A sobrevivência de A. citricola foi numericamente maior nas temperaturas de 20 e $25^{\circ} \mathrm{C}$ onde fềmeas chegaram a sobreviver de 15 a 19 dias e de 14 a 18 dias respectivamente. $\mathrm{Na}$ temperatura de $30^{\circ} \mathrm{C}$, a sobrevivência não ultrapassou 8 dias. A alta sobrevivência observada nas temperaturas abaixo de $30^{\circ} \mathrm{C}$ deve-se à menor atividade metabólica do inseto, quando comparada às temperaturas mais altas (Figura 11).
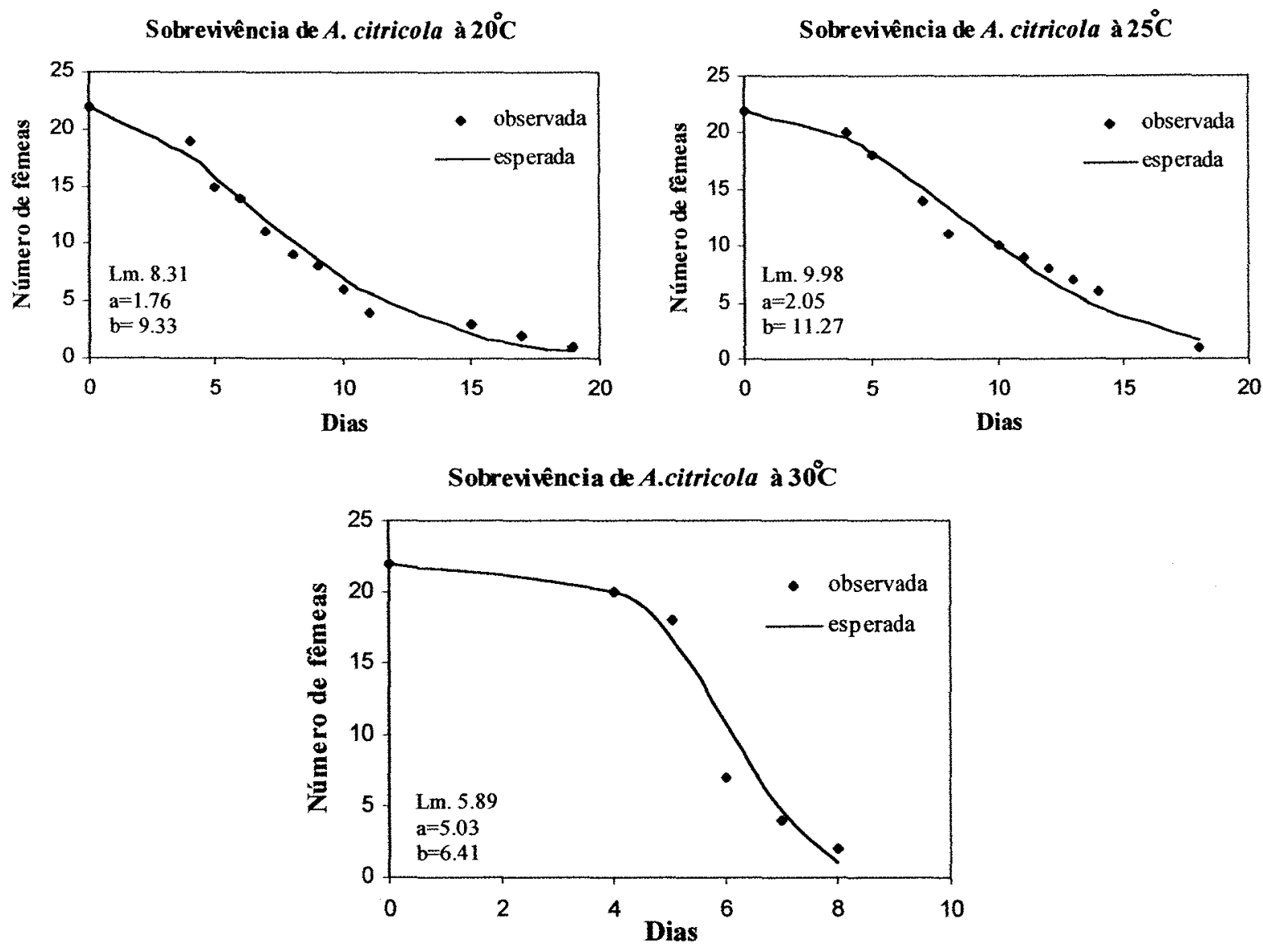

Figura 11 - Curvas de sobrevivência observada e esperada de 22 fềmeas de $A$. citricola nas temperaturas de 20,25 e $30^{\circ} \mathrm{C}$, UR: $70 \pm 10 \%$ e fotofase $14 \mathrm{~h}$, segundo o modelo de distribuição de Weibull. 
A alta sobrevivência observada na presente pesquisa atesta a eficiência do método de criação utilizado, mantendo-se a planta em tubetes, pois produziu insetos de ótima qualidade. Os valores significativos obtidos nas temperaturas de 20,25 e $30^{\circ} \mathrm{C}$ através do modelo de Weibull segundo a equação $y=\exp \left[-(t / b)^{a}\right]$, permitem estimar a longevidade da espécie em laboratório, facilitando a previsão de sua produção em larga escala.

\subsubsection{Número de pupas de $A$. citricola por hospedeiro, viabilidade pupal e duração do período ovo - adulto do parasitóide em três temperaturas}

Dentre as temperaturas de 20,25 e $30^{\circ} \mathrm{C}$, a média de pupas de $A$. citricola por hospedeiro foi maior a $25^{\circ} \mathrm{C}$ e menor a $30^{\circ} \mathrm{C}$, com uma variação de 5,60 a 3,90 pupas/hospedeiro, respectivamente (Tabela 9 e Figura 12). Observou-se a ocorrência de 1 a 7 pupas de $A$. citricola por hospedeiro nas temperaturas testadas, sendo mais freqüente 2 pupas/ hospedeiro (Tabela 8 ).

Eventualmente, durante a manutenção das populações de $A$. citricola no Laboratório de Biologia de Insetos, pôde-se ser observado um máximo de até 10 pupas do parasitóide em um hospedeiro, coincidindo com as observações de Logvinovskaya (1983), Smith \& Hoy (1995) e Edwards \& Hoy (1998). Argov \& Rössler (1998) observaram um máximo de 9 pupas em laboratório.

Por outro lado, em condições de campo, o número de pupas do parasitóide/ hospedeiro variou de 1 a 4 (Hoy \& Nguyen, 1994), 1 a 8 (Hoy et al., 1997), 1 a 9 (Willink et al., 1998), e de 1 a 7 durante a execução do presente ensaio. Assim, observou-se que tanto em condições de laboratório ou campo, o número máximo de pupas de $A$. citricola observado por hospedeiro tem sido 10. Estes números são baixos se comparados com Ageniaspis fusciocollis, que nos lepidópteros Yponomeuta spp. pode produzir mais de 100 indivíduos e Acrolepia assectella Zeller, de 10 a 15 indivíduos (Nénon ${ }^{4}$ citado por Edwards \& Hoy, 1998). 
Tabela 8. Ocorrência (\%) de diferentes números de pupas de $A$. citricola/hospedeiro a 20,25 e $30^{\circ} \mathrm{C}$, UR: $70 \pm 10 \%$ e fotofase $14 \mathrm{~h}$.

\begin{tabular}{|c|c|}
\hline $\mathrm{n}^{0}$ de pupas de & ocorrência $^{1,2}$ \\
\hline A. citricola /hospedeiro & $(\%)$ \\
\hline 1 & $10,16 \pm 0,94 \mathrm{~b}$ \\
\hline 2 & $14,17 \pm 1,49 \mathrm{a}$ \\
\hline 3 & $5,67 \pm 0,71 \mathrm{c}$ \\
\hline 4 & $1,51 \pm 0,25 \mathrm{~d}$ \\
\hline 5 & $0,26 \pm 0,09 \mathrm{de}$ \\
\hline 6 & $0,13 \pm 0,07 \mathrm{e}$ \\
\hline 7 & $0,01 \pm 0,01 \mathrm{e}$ \\
\hline
\end{tabular}

T'Médias seguidas de mesma letra na vertical não diferem entre si, pelo teste de Tukey, ao nível de $5 \%$ de probabilidade.

${ }^{2}$ Dados transformados para $\sqrt{ }(x+1)$

A viabilidade pupal de $A$. citricola foi de $58,40 \%$ a $20^{\circ} \mathrm{C}$, valor superior àquele obtido nas temperaturas de 25 e $30^{\circ} \mathrm{C}$. Não houve diferença estatística na viabilidade pupal entre as temperaturas de 25 e $30^{\circ} \mathrm{C}$ (Tabela 9 e Figura 12).

Tabela 9. Freqüência média de pupas de $A$. citricola por hospedeiro, viabilidade pupal e duração do período ovo - adulto do parasitóide em três temperaturas, UR: $70 \pm 10 \%$ e fotofase $14 \mathrm{~h}$.

\begin{tabular}{cccc}
\hline $\begin{array}{c}\text { Temp. } \\
\left({ }^{\circ} \mathrm{C}\right)\end{array}$ & $\begin{array}{c}\text { média de } \\
\text { pupas/ hospedeiro }\end{array}$ & $\begin{array}{c}\text { viabilidade pupal } \\
\text { (1,2 }\end{array}$ & $\begin{array}{c}\text { duração do período } \\
\text { ovo - adulto (dias) }\end{array}$ \\
\hline $20^{\circ} \mathrm{C}$ & $4,25 \pm 1,01 \mathrm{ab}$ & $58,39 \pm 4,64 \mathrm{a}$ & $23,59 \pm 0,35 \mathrm{a}$ \\
$25^{\circ} \mathrm{C}$ & $5,57 \pm 1,16 \mathrm{a}$ & $43,89 \pm 1,85 \mathrm{~b}$ & $18,11 \pm 0,22 \mathrm{~b}$ \\
$30^{\circ} \mathrm{C}$ & $3,86 \pm 0,83 \mathrm{~b}$ & $32,32 \pm 3,15 \mathrm{~b}$ & $13,81 \pm 0,18 \mathrm{c}$
\end{tabular}

${ }^{\top}$ Médias seguidas de mesma letra na vertical não diferem entre si, pelo teste de Tukey, ao nivel de $5 \%$ de probabilidade.

${ }^{2}$ Dados transformados para $\sqrt{ }(x+1)$

${ }^{3}$ Dados não transformados

${ }^{4}$ NÉNON, J.P. La polyembryonie de Ageniaspis fuscicolis Thoms. (Hyménoptère, Chalcidien, Encyrtidé). Bull.Biol.. Fr. Bbelg, v.42, p.13-107, 1978. 


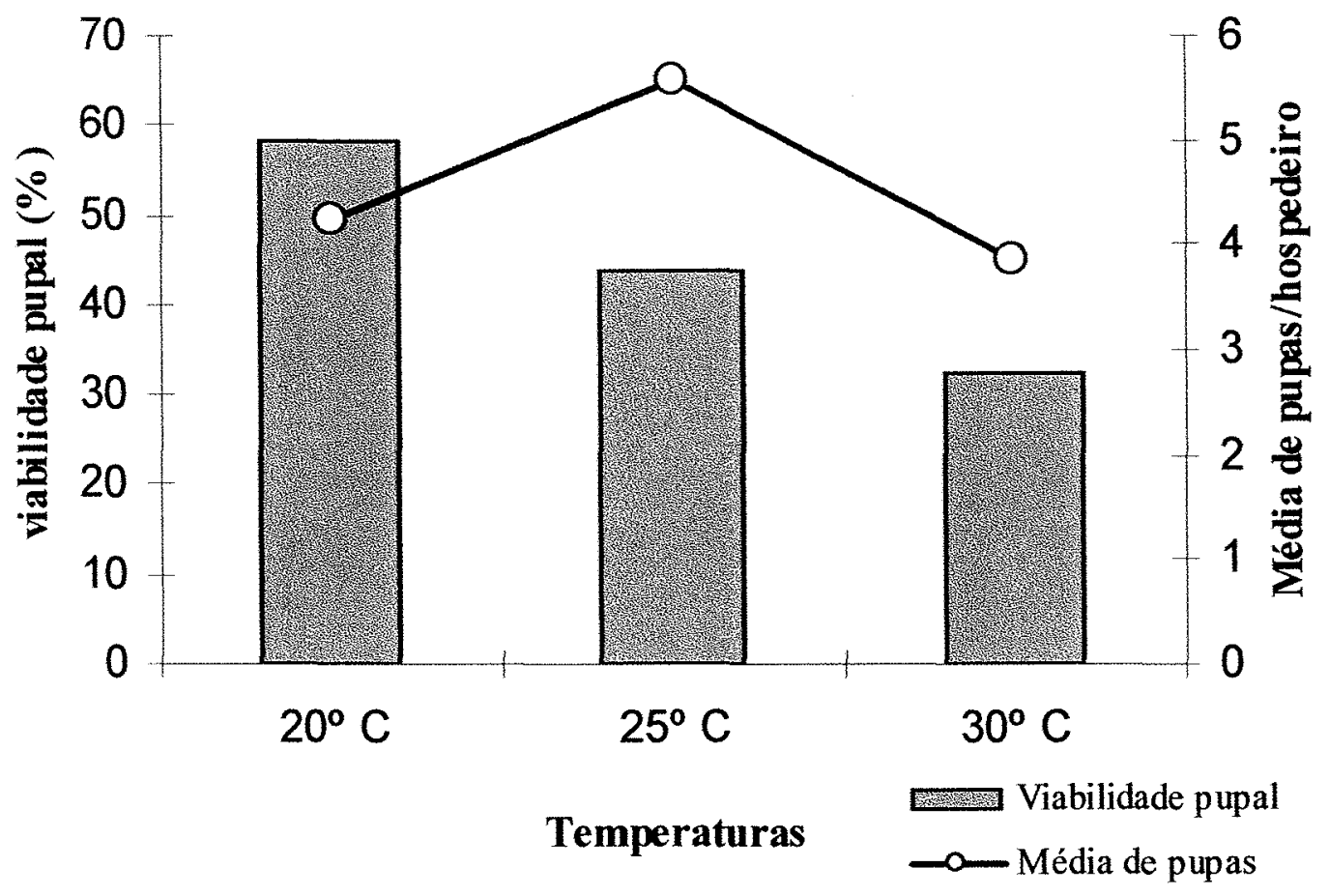

Figura 12 - Média de pupas e viabilidade pupal (\%) de A. citricola em três temperaturas, UR: $70 \pm 10 \%$ e fotofase $14 \mathrm{~h}$.

A duração do período ovo - adulto de $A$. citricola diferiu entre as temperaturas, sendo mais longa a $20^{\circ} \mathrm{C}$ (Tabela 9 e Figura 13). Na temperatura de $25^{\circ} \mathrm{C}$, o ciclo de vida do parasitóide foi de 18 dias, valor superior àquele observado por Argov \& Rössler (1998) e idêntico ao observado por Chagas ${ }^{5}$ (citado por Parra, 2000) nesta mesma condição. Na temperatura de $30^{\circ} \mathrm{C}$, como era de se esperar, devido à alta taxa metabólica nesta temperatura, o período ovo - adulto foi de 13 dias, valor inferior àqueles encontrado por Smith \& Hoy (1995) (16 a 18 dias) e Sacarías \& Canales (1999) (14 a 38 dias) e próximo ao descrito por Chagas ${ }^{5}$ (citado por Parra, 2000)

${ }^{5}$ CHAGAS, op. cit., p.14 


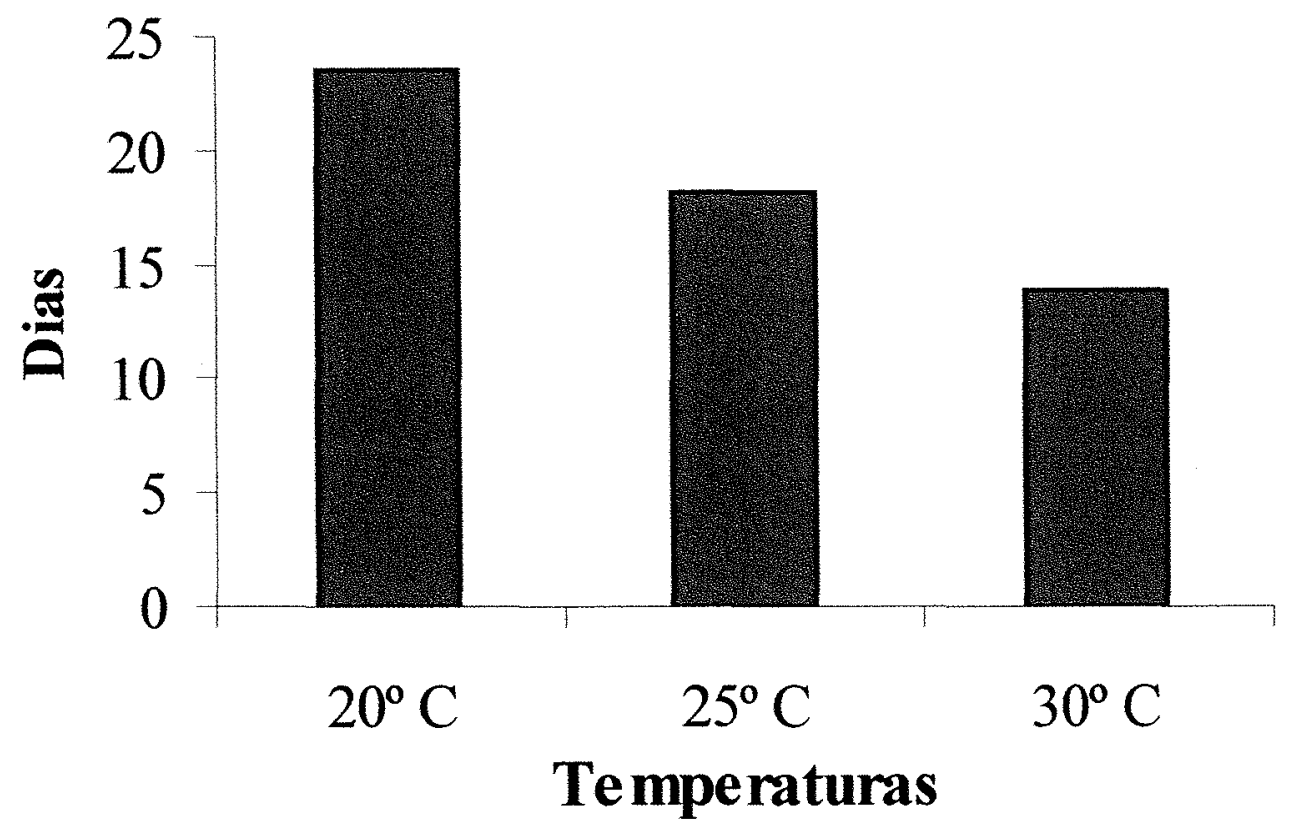

Figura 13 - Duração do período ovo - adulto de $A$. citricola a 20,25 e $30^{\circ} \mathrm{C}$, UR: $70 \pm 10 \%$ e fotofase $14 \mathrm{~h}$.

Em linhas gerais, considerando-se os diferentes aspectos analisados e, principalmente, o maior número de pupas produzidas por ovo parasitado, recomenda-se que a temperatura de $25^{\circ} \mathrm{C}$ seja utilizada para a criação de $A$. citricola para programas de Controle Biológico Clássico com a espécie. Como em tais criações, o objetivo é a produção de grandes quantidades de insetos, o parâmetro mencionado é de grande relevância, pois nos demais aspectos biológicos estudados não houve diferenças nas três temperaturas. Por outro lado, é desaconselhável a criação na temperatura de $20^{\circ} \mathrm{C}$, por alongar o período ovo-adulto, levando a uma menor produção de insetos num determinado período de tempo. Desta forma, a temperatura de $25^{\circ} \mathrm{C}$ é a mais adequada para a manutenção de A. citricola em laboratório, utilizando-se os parâmetros estudados, incluindo-se o modelo de distribuição de Weibull para previsão de sobrevivência, desde que os resultados obtidos seguiram tal distribuição (Fig. 11). Como o inseto vinha sendo 
criado a $25^{\circ} \mathrm{C}$, pode ter havido um condicionamento pré-imaginal, fato não avaliado na presente pesquisa, sugerindo-se estudos nesta direção.

Em estudos de produção de inimigos naturais, é muito importante conhecerem-se as exigências térmicas do parasitóide, principalmente no presente caso em que há necessidade de perfeito sincronismo entre planta, parasitóide e hospedeiro. Assim, com câmaras climatizadas reguladas em diferentes temperaturas torna-se mais fácil tal sincronização, pois pôde ser observado que há alongamento do ciclo nas temperaturas mais baixas $\left(20^{\circ} \mathrm{C}\right)$ e encurtamento nas temperaturas mais altas $\left(30^{\circ} \mathrm{C}\right)$; com base nas exigências térmicas do parasitóide (Chagas et al. 2000b citado por Parra 2000) a criação poderá ser facilitada.

\subsection{Comparação de técnicas de liberação de $A$. citricola em campo e da idade de pupas do parasitóide a serem colocadas nestes recipientes.}

Não houve diferenças na emergência de adultos de $A$. citricola nas 2 técnicas de liberação utilizadas bem como entre idade das pupas em condições campo (Tabela 10).

A instalação dos recipientes no meio das copas das árvores, evitou a ação direta da luz solar. Este procedimento aliado à quantidade de umidade colocada em copos e tubetes, e o período chuvoso durante a condução do experimento, permitiram a manutenção de umidade.

Embora não tenha havido diferenças na emergência dos parasitóides em ambos os recipientes, o copo plástico é mais barato além de permitir a colocação de um maior volume de folhas contendo pupas do parasitóide. A utilização de recipientes de liberação contendo pupas tem como desvantagem o fato de exigir a manutenção de umidade. Entretanto, tem a grande vantagem de reduzir a mão-de-obra em relação à liberação de adultos em condições de campo. 
Tabela 10. Comparação de técnicas de liberação de $A$. citricola em campo e da idade de pupas do parasitóide a serem colocadas nestes recipientes, em duas liberações realizadas em pomar de citros da ESALQ/USP.

\begin{tabular}{lr}
\hline \multicolumn{1}{c}{ Técnica } & emergência (\%) \\
\hline Copo & $97,33 \pm 1,09 \mathrm{a}$ \\
Tubete & $97,83 \pm 0,78 \mathrm{a}$ \\
Idade de pupas & \\
1 & $99,00 \pm 0,78 \mathrm{a}$ \\
2 & $97,25 \pm 1,50 \mathrm{a}$ \\
3 & $96,50 \pm 1,06 \mathrm{a}$
\end{tabular}

${ }^{T}$ Médias seguidas de mesma letra na vertical não diferem entre si, pelo teste de Tukey, ao nível de 5\% de probabilidade; dados não transformados

\subsection{Espécies de parasitóides nativos de $P$. citrella encontrados em pomares do} Estado de São Paulo 1 ano após o início das liberações de $A$. citricola.

Foram identificados, 1 ano após as liberações de $A$. citricola (Figura 14), iniciadas em outubro de 1998, os seguintes parasitóides nativos com as respectivas porcentagens de ocorrência: Galeopsomyia fausta LaSalle, 66,22\% (Figura 15); Cirrospilus sp., 29,05\%; Elasmus sp., 2,70\%; Eupelmus sp., 1,35\% e de Chrysocharis sp. $0,67 \%$.

O parasitóide G. fausta foi o mais abundante nas amostragens, seguido por Cirrospilus sp., enquanto que Elasmus sp. (embora tenha ocorrido em pequena porcentagem nas amostragens das fazendas), foi o parasitóide mais comum nos telados de criação de $P$. citrella pertencentes ao Laboratório de Biologia de Insetos da ESALQ/USP, campus de Piracicaba-SP.

Nas amostragens realizadas por Costa et al., (1999) em Jaguariúna no período de 1996 a 1997 ou seja, anteriormente à introdução de A. citricola, G. fausta foi o parasitóide mais abundante ocorrendo em $90 \%$ das amostragens. Contudo, após a introdução do parasitóide exótico, a porcentagem de G. fausta em campo caiu para 
$38,30 \%$ enquanto que $A$. citricola apresentou-se em $60,10 \%$ das amostras na mesma região (Sá et al., 2000).

Portanto, aparentemente, $A$. citricola está ocupando o nicho ecológico anteriormente ocupado pelos parasitóides nativos. Pesquisas sobre o impacto ambiental desta alteração no ecossistema bem como o efeito de $A$. citrícola na redução da população do minador e incidência do cancro cítrico deverão ser estudados nos próximos anos. 


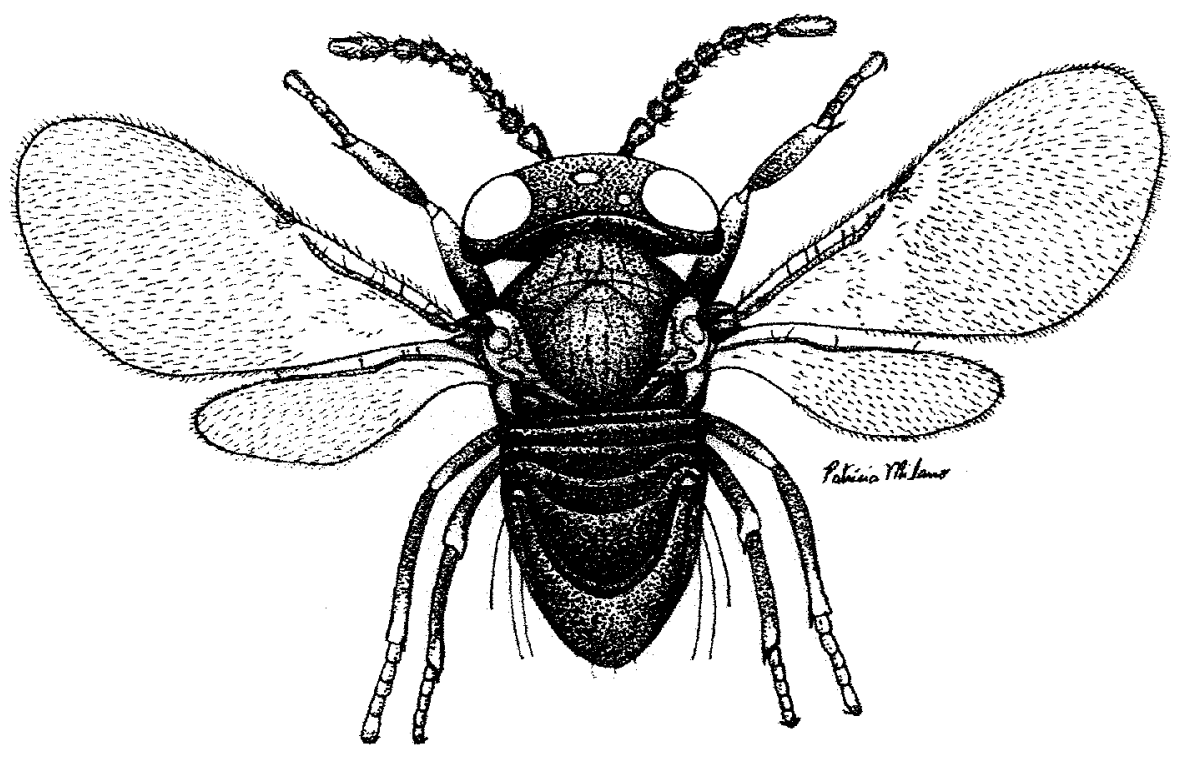

Figura 14 - Macho de Ageniaspis citricola, com os dois primeiros antenômeros de igual tamanho e maiores em relação aos da fêmea.

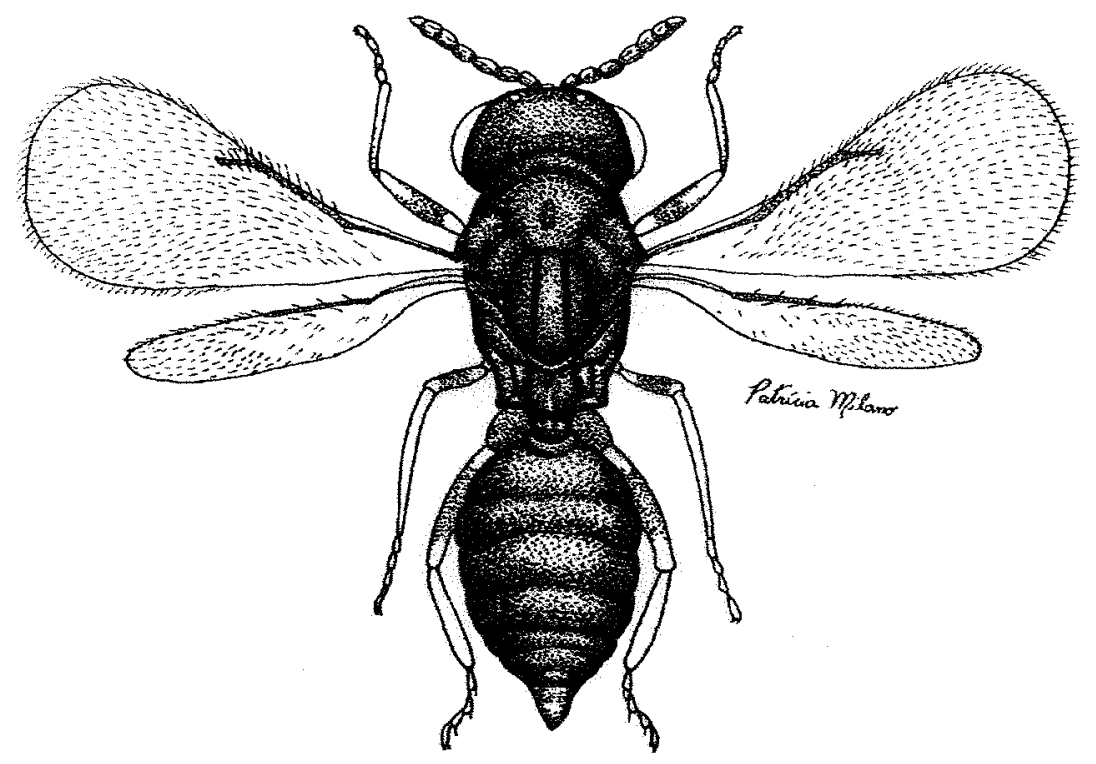

Figura 15 - Adulto de Galeopsomyia fausta 


\subsection{Verificação da adaptação de $A$. citricola $\mathrm{em}$ pomares de citrus 3 anos após sua introdução no Brasil}

Constatou-se que $A$. citricola foi capaz de se dispersar a partir dos pontos de liberação para locais distantes, em todas a propriedades pertencentes ao grupo FISCHER S/A Agropecuária no Estado de São Paulo, distribuindo-se na região Norte, Centro e Sul do estado.

$\mathrm{Na} 1^{\mathrm{a}}$ amostragem, realizada em dezembro de 2000 , as porcentagens de parasitismo de $A$. citricola foram baixas quando comparadas às médias obtidas na $2^{\text {a }}$ amostragem realizada em fevereiro de 2001 (Tabela 11 e Figura 16).

Quando comparadas as regiões, observou-se que a região Sul apresentou maiores índices de parasitismo (Tabela 11) concordando com o levantamento realizado pelo grupo FISCHER (Helton C. Leão ${ }^{6}$ informação pessoal), onde este índice chegou a $33 \%$. A região Central, embora tenha apresentado menor parasitismo na $1^{\text {a }}$ amostragem, acompanhou a região Sul em níveis de parasitismo que atingiram $81,61 \%$ na $2^{\mathrm{a}}$ amostragem e $31 \%$ em levantamentos do grupo FISCHER.

Tabela 11. Porcentagem de parasitismo por $A$. citricola na $1^{\mathrm{a}}$ e $2^{\mathrm{a}}$ amostragens de brotações de citros nas fazendas do estado de São Paulo pertencentes ao grupo FISCHER S/A Agropecuária ${ }^{1}$.

\begin{tabular}{ccccc}
\hline Regiões & \multicolumn{2}{c}{$1^{\mathrm{a}}$ amostragem } & \multicolumn{2}{c}{$2^{\mathrm{a}}$ amostragem } \\
\hline & Brotações & Média de & Brotações & Média de \\
Norte & avaliadas & parasitismo & avaliadas & parasitismo \\
Centro & 2107 & $3,14 \%$ & 305 & $64,96 \%$ \\
Sul & 2601 & $1,75 \%$ & 2245 & $81,61 \%$ \\
\hline
\end{tabular}

${ }^{1} 16$ fazendas amostradas

${ }^{6}$ LEÃO, H.C. Informação pessoal, 2001 
Estes resultados concordam com observações realizadas por Parra et al., (2001) que a partir de 700.000 plantas amostradas em 17 propriedades abrangendo as regiões Norte, Centro e Sul do Estado de São Paulo, observaram porcentagens médias de parasitismo por este encirtídeo de $32,9 \%$ na região Sul (mais úmida) contra $4,4 \%$ na região Norte (mais seca).

As condições para o sucesso de $A$. citricola no controle de $P$. citrella dependem da presença de brotações em campo, presença do minador na fase de ovo ou de lagartas de $1^{\circ}$ instar antes das liberações e ausência de aplicações de inseticidas (Hoy \& Nguyen, 1997).

A escolha de $A$. citricola em relação a outros parasitóides como agente de controle do minador, deveu-se não somente à sua alta especificidade (Neale et al., 1995) mas também à sua alta taxa de reprodução (poliembrionia, com média de 3 pupas por hospedeiro, onde cada fềmea pode produzir até 180 descendentes), habilidade de localizar populações isoladas e pequenas do minador e alta taxa de dispersão (300 km na Austrália e 860.000 acres na Flórida, EUA) após 3 anos a partir das liberações (Hoy \& Nguyen, 1997).

O sucesso do programa de controle do minador em Queensland (Austrália) e Flórida (EUA) deveu-se não somente às características de $A$. citricola citadas mas também pela semelhança climática entre estas regiões e às áreas de coletas do parasitóide na Ásia, observando-se que $A$. citricola adapta-se melhor em climas quentes e úmidos (Hoy \& Nguyen, 1997).

Em São Paulo, portanto, o parasitóide está totalmente adaptado e mesmo nas regiões mais secas chegou a representar $60 \%$ do parasitismo (Figura 16). A capacidade de dispersão do parasitóide, embora não avaliada na Brasil, é muito alta, pois ele tem sido encontrado a muitos $\mathrm{Km}$ de distância dos locais de liberação. Portanto, as condições climáticas do nosso país tem sido muito favoráveis ao inseto, pois ele tem se mostrado muito rústico e tem estado presente mesmo em áreas com aplicações de inseticidas e acaricídas. 


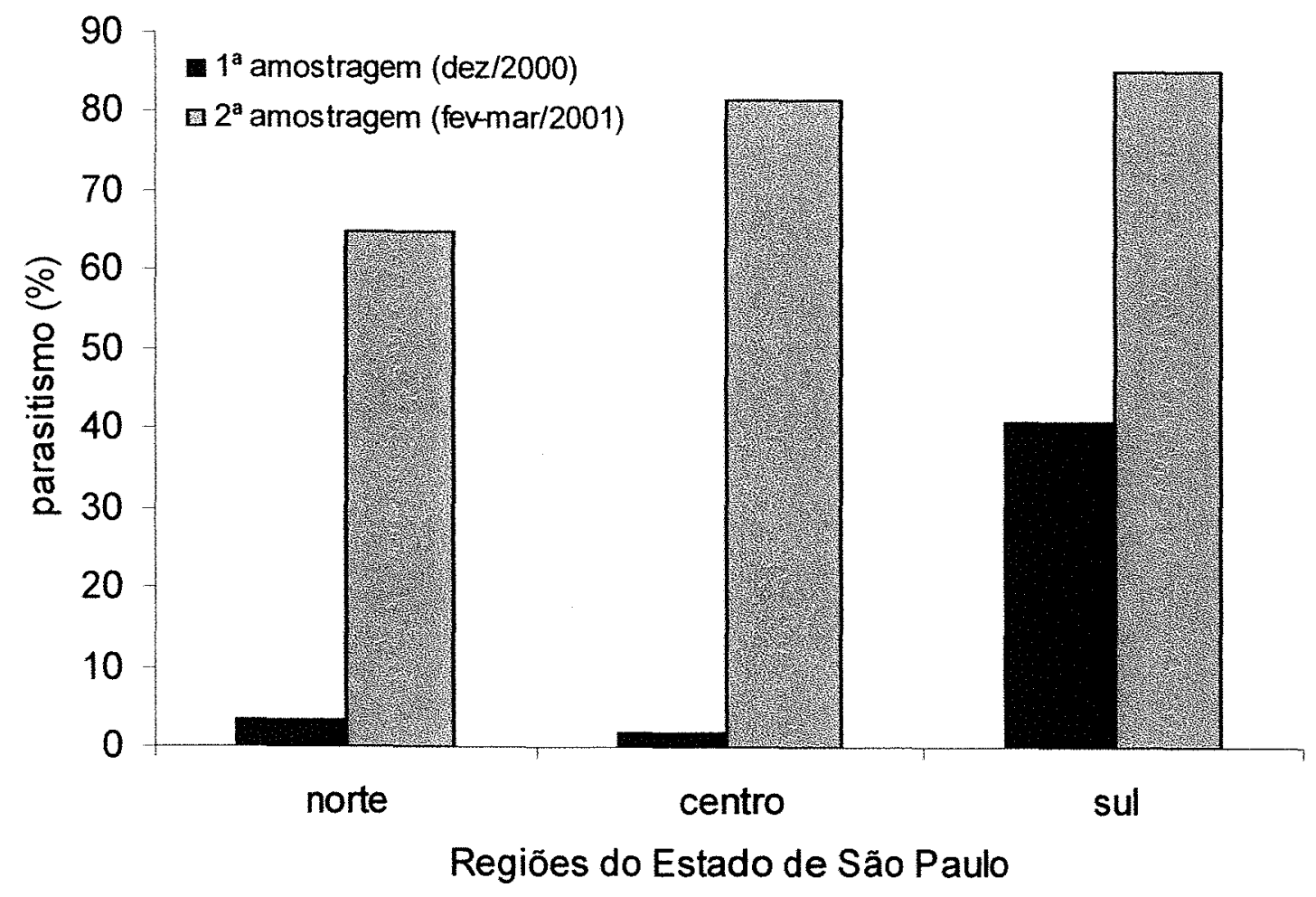

Figura 16 - Porcentagem de parasitismo de $A$. citricola nas regiões norte, centro e sul do estado de São Paulo 3 anos após a liberação do parasitóide, em duas amostragens de campo. 


\section{CONCLUSÕES}

a) A proporção de 2 casais de Phyllocnistis citrella Stainton, 1856 por planta de citros em tubetes é a mais adequada para a obtenção de ovos para a criação de $P$. citrella e de Ageniaspis citricola Logvinovskaya, 1983.

b) O sistema de produção de $P$. citrella em tubetes é mais econômico, ocupando menos espaço do que o sistema em mudas de 10 meses, facilitando experimentos em condições controladas.

c) O comportamento do minador é variável entre variedades de citros, em teste de confinamento e livre escolha.

d) Não existe diferença de parasitismo por $A$. citricola entre ovos e lagartas de $1^{\circ}$ instar de $P$. citrella.

e) Considerando-se a média de pupas de por hospedeiro, viabilidade pupal e a duração do ciclo de $A$. citricola, recomenda-se a temperatura de $25^{\circ} \mathrm{C}$ para a criação do parasitóide em laboratório.

f) Não há diferenças na emergência de $A$. citricola em copos plásticos ou tubetes utilizados para liberação no campo. 
g) A idade de pupas, utilizadas para liberação no campo, não afeta a emergência de $A$. citricola.

h) Dentre as espécies de parasitóides identificadas em 16 fazendas do Estado de São Paulo, Galeopsomyia fausta LaSalle é a mais abundante.

i) Embora totalmente adaptado no Brasil, três anos após a sua introdução, A. citricola, ocorre em maior porcentagem nas regiões Sul e Centro do estado de São Paulo. 


\section{REFERÊNCIAS BIBLIOGRÁFICAS}

ALBA, C.G. El minador de los citricos, Phyllocnistis citrella, Stainton. Introduccion y comportamento en España. Descripción, daños y caracterización ecologica: estrategia de lucha. Malaga: Consejeria de Agricultura y Pesca, 1996. 18 p.

ARGOV, Y.; RÖSSLER, Y. Introduction, release and recovery of several exotic natural enemies for biological control of the citrus leafminer, Phyllocnistis citrella, in Israel. Phytoparasitica, v.24, p.33-38, 1996.

ARGOV, Y.; RÖSSLER, Y. Rearing methods for the citrus leafminer Phyllocnistis citrella Stainton, and its parasitoids in Israel. Biological Control, v.11, p.18-21, 1998.

AVILES, D. Primeiro relato da ocorrência do minador dos citros (Phyllocnistis citrellaLepidoptera: Phyllocnistidae) em Rondônia. In: CONGRESSO BRASILEIRO DE ENTOMOLOGIA, 16., Salvador, 1997. Resumos. Salvador: SEB, 1997. p.88.

BA-ANGOOD, S.A.S. A contribution to the biology and occurrence of the citrus leafminer, Phyllocnistis citrella Stainton (Lepidoptera: Gracillariidae) in the Sudan. Zeitschrift fur Angewandte Entomologie, v.83, p.106-111, 1977. 
BADAWY, A. The morphology and biology of Phyllocnistis citrella Stainton, a citrus leafminer in the Sudan. Bulletin de la Societe Entomologique du Egypte, v.51, p.95-103, 1967.

BATRA, R.C.; SANDHU, S.C.; SHARMA, S.C.; SINGH, R. Biology of the citrus leafminer on some rootstocks and its relationships with abiotic factors. The Punjab Horticultural Journal, v.28, n.2, p.30-35, 1988.

BAUTISTA, M.; CARRILLO, S.J.L.; BRAVO, M.H.; KOCH, S.D. Natural parasitism of Phyllocnistis citrella (Lepidoptera: Gracillariidae) at Cuitlahuac, Veracruz, México. Florida Entomologist, v.81, n.1, p.30-37, 1998.

BROWNING, H.; PEÑA, J.E. Biological control of the citrus leafminer by its native parasitoids and predators. Citrus Industry, v.76, n.4, p. 12-14, 1995.

CHAGAS, M.C.M. Phyllocnistis citrella Stainton, 1856 (Lepidoptera: Gracillariidae): Bioecologia e relação com o cancro cítrico. Piracicaba, 1999. 67p. Tese (Doutorado)- Escola Superior de Agricultura "Luiz de Queiroz", Universidade de São Paulo.

CHAGAS, M.C.M.; PARRA, J.R.P. Phyllocnistis citrella Stainton (Lepidoptera: Gracillariidae): técnica de criação e biologia em diferentes temperaturas. Anais da Sociedade Entomológica do Brasil, v.29, p.227-235, 2000.

CHAGAS, M.C.M.; PARRA, J.R.P.; NAMEKATA, T.; HARTUNG, J.S.; YAMAMOTO, P.T. Phyllocnistis citrella Stainton (Lepidoptera: Gracillariidae) and its relationship with the citrus canker bacterium Xanthomonas axonopodis pv citri in Brasil. Neotropical Entomology, v.30, p.55-59, 2001. 
CÔNSOLI, F.L.; ZUCCHI, R.A.; LOPES, J.R.S. A lagarta minadora dos citros Phyllocnistis citrella Stainton, 1856 (Lepidoptera: Gracillariidae: Phyllocnistinae) Piracicaba: FEALQ, s.d. 39p.

COSTA, V.A.; SÁ, L.A.N. de; LASALLE, J.; NARDO, E.A.B. de; ARELLANO, F.; FUINI, L.C. Indigenus parasitoids (Hymenoptera: Chalcidoidea) of Phyllocnistis citrella Stainton (Lepidoptera: Gracillariidae) in Jaguariúna, São Paulo State, Brazil: preliminary results. Journal of Applied Entomology, v.123, p.237-240, 1999.

COOK, A.A. Association of citrus canker pustules with leafminer tunnels in North Yemen. Plant Disease, v.72, p.546, 1988.

DIDONET, J.; AGUIAR, R.W.S.; PANATO, A.P. Ocorrência e infestação de larva minadora dos citros Phyllocnistis citrella (Lepidoptera: Gracillariidae) no Estado do Tocantins. In: CONGRESSO BRASILEIRO DE ENTOMOLOGIA, 17., Rio de Janeiro, 1998. Resumos. Rio de Janeiro: SEB, 1998. p.217.

EDWARDS, O. R.; HOY, M.A. Biology of Ageniaspis citricola (Hymenoptera: Encyrtidae), a parasitoid of the leafminer Phyllocnistis citrella (Lepidoptera: Gracillariidae). Annals of the Entomological Society of America, v.91, p.654$660,1998$.

EVANS, G. Discovery of the male of Ageniaspis citricola (Hymenoptera: Encyrtidae), a parasitoid of the citrus leafminer, Phyllocnistis citrella (Lepidoptera: Gracillariidae). Florida Entomologist, v.78, p.134-136, 1995.

GARIJO, A.; GARCÍA, J.G.. Minador de las hojas de los cítricos Phyllocnistis citrella Stainton. Phytoma, v.58, p.220-223, 1994. 
GARIJO, C.; GARCÍA, E.J.. Phyllocnistis citrella (Stainton, 1856) (Insecta: Lepidoptera: Gracillariidae: Phyllocnistinae) en los cultivos de cítricos de andalucía (Sur España): biologia, ecología y control de la plaga. Boletin de Sanidad Vegetal. Plagas, v.20, n.4, p. 815-816, 1994.

GARRIDO, A. Phyllocnistis citrella Stainton, aspectos ecológicos e enemigos naturales encontrados en España. Levante Agrícola, n.330, p.13-21, 1995.

GRAVENA, S. "Minadora das folhas dos citros": a mais nova ameaça da citricultura brasileira. Laranja, v.15, p.397-404, 1994.

GRAVENA, S. "Vespinha importada controla Minadora": Ageniaspis citricola, a microvespa que veio da Flórida, se deu bem na citricultura brasileira e foi um sucesso no controle biológico da Minadora dos Citros. Citricultura Atual, n.22, p.14-15, 2001.

HEPPNER, J.B. Citrus leafminer, Phyllocnistis citrella, in Flórida (Lepidoptera: Gracillariidae: Phyllocnistinae). Tropical Lepidoptera, v.4, p.49-64, 1993.

HEPPNER, J.B. Citrus leafminer (Lepidoptera: Gracillariidae) on fruit in Florida. Florida Entomologist, v.78, n.1, p.182-186, 1995.

HOY, M.A.; NGUYEN, R. Current status of Ageniaspis citricola, a parasite of the citrus leafminer, in Florida. Citrus Industry, v. 75, n.12, p.30-32, 1994.

HOY, M.A.; NGUYEN, R.; POMERINK, M.; BULLOCK, R.; HALL, D.; KNAPP, J.; PENA, J.; BROWNING, H.; STANSLY, P. Distribution of $A$. citricola- a parasite of the citrus leafminer. Citrus Industry, v. 78, n.5, p. 51-52, 1997. 
HOY, M.A.; NGUYEN, R.; Classical biological control of the citrus leafminer Phyllocnistis citrella Stainton (Lepidoptera: Gracillariidae): Theory, practice, art and science. Tropical Lepidoptera, suppl. 1, p. 19, 1997.

HUANG, M.D.; LI, S.X. Studies on the integrated management of citrus insect pest. Guangzhou: Academic Book \& Periodical Press, 1989. p 84-89: The damage and economic threshold of citrus leafminer, Phyllocnistis citrella Stainton to citrus.

HUTSON, J.C.; PINTO, M.P.D. Two caterpillar pests of citrus. Tropical Agriculturist, v.83, p.188-193, 1934.

JACAS, J.A.; GARRIDO, A. Differences in the morphology of male and female of Phyllocnistis citrella (Lepidoptera: Gracillariidae). Florida Entomologist, v.79, n.4, p.603-606, 1996.

LA SALLE, J.; PEÑA, J.E. A new species of Galeopsomyia (Hymenoptera: Eulophidae: Tetrastichinae): a fortuitous parasitoid of the citrus leafminer, Phyllocnistis citrella (Lepidoptera: Gracillariidae: Phyllocnistinae). Florida Entomologist, v.80, p.461$470,1997$.

LATIF, A.L.; YUNUS, C.M. Food plants of citrus leafminer in Punjab. Bulletim of the Entomological Research, v.42, p.311-316, 1951.

LEGASPI, J.C.; FRENCH, J.V.; ZUÑIGA, A.G. LEGASPI Jr., B.C. Population dynamics of the citrus leafminer, Phyllocnistis citrella (Lepidoptera: Gracillariidae), and its natural enemies in Texas and México. Biological Control, v.21, p.84-90, 2001.

LIMA, AF; AGUIAR, L.A. Ocorrência e infestação de larva minadora dos citros Phyllocnistis citrella (Lepidoptera: Gracillariidae)no Estado do Rio de Janeiro. In: 
CONGRESSO BRASILEIRO DE ENTOMOLOGIA, 16., Salvador, 1997. Resumos. Salvador: SEB, 1997. p.229.

LOGVINOVSKAYA, T.V. A new species of Ageniaspis Dahlbom 1857 (Hymenoptera, Encyrtidae) from Vietnam. Entomological Review, v.62, p.150-152, 1983.

LOPES, C.M.D'A.; PAMPLONA, A.M.S.R., TELES, B.R. Ocorrência e levantamento do minador das folhas de citros Phyllocnistis citrella (Lepidoptera: Gracillariidae)no Estado do Amazonas. In: CONGRESSO BRASILEIRO DE ENTOMOLOGIA, 16., Salvador, 1997. Resumos. Salvador: SEB, 1997. p.285.

LOURENÇÃO, A.L.; MÜLLER, G.W.; PRATES, H.S. "Minador das folhas dos citros": praga exótica potencialmente importante para a citricultura brasileira. Campinas: CATI, 1994. 2p. (CATI. Comunicado Técnico, 118).

MOREIRA, M.AB.; MEDEIROS, R.D.; DUARTE, O.R.. Ocorrência e avaliação do dano da largarta minadora dos citros Phyllocnistis citrella (Lepidoptera: Gracillariidae) em Roraima. In: CONGRESSO BRASILEIRO DE ENTOMOLOGIA, 16., Salvador, 1997. Resumos. Salvador: SEB, 1997. p.88.

NASCIMENTO, A.S.; VIDAL, C.A. Ocorrência de parasitóides e local de preferência para desenvolvimento da larva do minador das folhas dos citros Phyllocnistis citrella Station, 1856, em Cruz das Almas, BA. In: CONGRESSO BRASILEIRO DE ENTOMOLOGIA, 17., Rio de Janeiro, 1998. Resumos. Rio de Janeiro: SEB, 1998. p.324.

NEALE, C.; SMITH, D.; BEATTIE, G.A.C.; MLES, M. Importation host specificity testing rearing and release of three parasitoid of Phyllocnistis citrella Stainton (Lepidoptera: Gracillariidae) in Eastern Australia. Journal of The Australian Entomological Society, v. 34, p. 343-348, 1995. 
PANDEY, N.D.; PANDEY, Y.D. Bionomics of Phyllocnisitis citrella (Lepidoptera: Gracillariidae). Indian Journal of Entomology, v. 26, p.417-426, 1964.

PARRA, J.R.P. Phyllocnistis citrella: o minador-dos-citros: bioecologia e alternativas de controle. In: ENCONTRO SOBRE MINADOR DAS FOLHAS DOS CITROS, Campinas, 2000: Campinas: Instituto Biológico, 2000. p.20.

PARRA, J.R.P.; CHAGAS, M.C.M.; YAMAMOTO, P.T.; GRAVENA,S. MILANO,P. LEÃO, H.C. de ; MARQUES, A.; PARRA, A.L.G.C.; FIALHO, A. Ageniaspis citricola em citros no Brasil: visão geral, três anos após sua introdução. In: SIMPÓSIO DE CONTROLE BIOLÓGICO, 7, Poços de Caldas, 2001. Resumos. Poços de Caldas: SEB, 2001. p.20.

PEÑA, J.E.; DUNCAN, F.J. Control of citrus leafminer in south Florida: production. Proceedings of the Florida State for Horticultural Society, v.106, p.47-51, 1993.

PEÑA, J.E.; DUNCAN, R.; BROWNING, H. Seasonal abundance of Phyllocnistis citrella (Lepidoptera: Gracillariidae) and its parasitoids in south Florida citrus. Biological Control, v. 25, p.698-702, 1996.

PENTEADO-DIAS, A.M.; SANTIN, G.; PAIVA, P.E.B.; PINTO, R.A. Parasitóides de Phyllocnistis citrella (Stainton) (Lepidoptera: Gracillariidae: Phyllocinistinae) no Estado de São Paulo. Laranja, v.18, n.1, p.79-84, 1997.

PERIOTO, N.W. Primeira ocorrência do Gênero Galeopsomyia Girault (Hymenoptera: Chalcidoidea: Eulophidae) para o Brasil. O Biológico, v.59, n1, p.97-98, 1997. 
POMERINKE, M.A.; STANSLY. P.A. Establishment of Ageniaspis citricola (Hymenoptera: Encyrtidae) for biological control of Phyllocnistis citrella in Florida. Florida Entomologist, v.81, p.361-372, 1998.

PRATES, H.S.; NAKANO, O .; GRAVENA, S.A. "Minadora das folha de citros" Phyllocnistis citrella, Stainton, 1856. Campinas: CATI, 1996. 3p. (CATI. Comunicado Técnico, 129).

SÁ, L.A.N. de; COSTA, V.A.da. Ocorrência de parasitóides de Phyllocnistis citrella no município de Jaguariúna, SP: Resultados preliminares. In: CONGRESSO BRASILEIRO DE ENTOMOLOGIA, 16., Salvador, 1997. Resumos. Salvador: SEB, 1997. p.145.

SÁ, L.A.N. de; COSTA, V.A.da; OLIVEIRA, W.P. de; ALMEIDA, G.R.de. Parasitoids of Phyllocnistis citrella in Jaguariúna, state of São Paulo, Brazil, before and after the introduction of Ageniaspis citricola. Scientia Agricola, v.57, n.4, p.799-801, 2000 .

SÁ, L.A.N. de; COSTA, V.A.da; TAMBASCO, F.J.; OLIVEIRA, W.P. de; ALMEIDA, G.R.de. Parasitóides da larva-minadora-da-folha-dos-citros, Phyllocnistis citrella Stainton: laboratório de quarentena "Costa Lima" em Jaguariúna, SP. Jaguariúna: EMBRAPA Meio Ambiente, 1999. 4 p. (EMBRAPA Meio Ambiente. Comunicado Técnico, 2).

SÁ, L.A.N. de; COSTA, V.A.da; TAMBASCO, F.J.; OLIVEIRA, W.P. de; ALMEIDA, G.R.de; PEREIRA, R.A.A. Pos- introduction of the natural enemy Ageniaspis citricola in citrus groves em Jaguariúna and Aguaí region, São Paulo State, Brazil: preliminary results. In: INTERNATIONAL CONGRESS OF ENTOMOLOGY, 21., Foz de Iguaçu, 2000. Abstract book, Foz de Iguaçu, 2000. 
SABINE, B.N.E. Citrus leafminer. Queensland Agricultural Journal, v.20, p.127129, Feb. 1971.

SACARÍAS, E.N.; CANALES, A.C. Ageniaspis citricola Logvinovskaya, 1983 (Hymenoptera: Encyrtidae) controlador de Phyllocnistis citrella "minador de la hoja de los citricos": experiencia peruana. Lima: SENASA,1999. 88 p.

SCHAUFF, M.E.; LASALLE, J.; WIJESEKARA, G.A. The genera of Chalcidae parasitoids (Hymenoptera: Chalcidoidea) of citrus leafminer Phyllocnistis citrella Stainton (Lepidoptera: Gracillariidae). Journal of Natural History, v. 32, p. 10011056, 1998.

SGRILLO, R.B., A distrubuição de Weibull como modelo de sobrevivência de insetos. Ecossistema, v. 7, p. 9-13, 1982.

SMITH, J.M.; HOY, M.A. Rearing methods for Ageniaspis citricola (Hymenoptera: Encyrtidae) and Cirrospilus quadristriatus (Hymenoptera: Eulophidae) realeased in a classical biological control program for the citrus leafminer Phyllocnistis citrella (Lepidoptera: Gracillariidae). Florida Entomologist, v. 78, n.4, p. 601-608, 1995.

SMITH, J.M.; HOY, M.A. Rearing techniques for Ageniaspis citricola and Phyllocnistis citrella. In: Managing the citrus leafminer. s.e.: s.ed.,1996. p.99.

SOHI, G.S.; SANDHU, M.S. Relationship between Citrus leafminer (Phyllocnistis citrella Stainton) injury and Citrus canker [Xantomonas citri (Hasse) Dowson] incidence on citrus leaves. Journal of Research of the Punjab Agricultural University, v. 5, p. 66-69, 1968. 
SPONAGEL, K.W.; DÍAZ, F.J. El minador de las hojas de los citricos Phyllocnistis citrella, un insecto plaga de importancia económica en ia citricultura de Honduras. La Lima; FHA, 1994. 32p.

STEHR, F.W. Immature insects. Dubuque: Kendall/Hunt, v.1, 754 p.1987.

URBANEJA, A. Métodos alternativos de control sobre el minador de las hojas de los cítricos Phyllocnistis citrella Stainton (Lepidoptera: Gracillariidae): aceites minerales, azadiractina y parasitoides autóctonos. Proyecto final de carrera. Lleida: Universitat de Lleida, E.T.S.E.A., s.d. 161p.

URBANEJA, A.;JACAS, J.A.; VERDÚ, M.; GARRIDO, A. Dinámica e impacto de los prasitoides autóctonos de Phyllocnistis citrella Stainton em la Comunidad Valenciana. Investigaciones Agrarias. Série Protecion Vegetal, v.13, n.3, p.409$423,1998$.

URBANEJA, A.; LLÁCER, E.; GARRIDO, A.; JACAS, J.A. Effect of temperature on the life history of Cirrospilus sp. near lyncus (Hymenoptera: Eulophidae), a parasitoid of Phyllocnistis citrella (Lepidoptera: Gracillariidae). Biological Control, v. 21, p. 293-299, 2001.

URBANEJA, A.; LLÁCER, E.; TOMÁS, Ó.; GARRIDO, A.; JACAS, J.A. Indigenous natural enemies associated with Phyllocnistis citrella (Lepidoptera: Gracillariidae) in Eastern Spain. Biological Control, v. 18, p. 199-207, 2000.

VAZQUEZ MORENO, L.L.; PÉREZ VICENTE, I. Introduccion y dispersion del minador de la hoja de los citricos (Phyllocnisits citrella Stainton) em la Región Neotropical. Levante Agricola, p.4-7, jan./mar. 1997. 
WILLINK, E.; FIGUEROA, D.; ZAMUDIO, P.; H. Control biologico del minador de la hoja de los citricos. Avance Agroindustrial, v.18, n. 73, p. 14-18, 1998.

WILSON, C.G. Notes on Phyllocnisits citrella Stainton (Lepidoptera: Phyllocnistidae) attacking four citrus varieties in Darwin. Journal of the Australian Entomological Society, v. 30, p. 77-78, 1991.

ZHANG, A.; O' LEARY, C.; QUARLES, W. Chinese IPM for citrus leafminer. IPM Practioner, v.16, p. 10-13, 1994. 